University of Louisville

ThinkIR: The University of Louisville's Institutional Repository

6-1947

\title{
A survey of the safety departments and their two main constituents, police and fire departments, in cities of from 250,000 to 650,000 inhabitants in the United States.
}

Henry Buchtal

University of Louisville

Follow this and additional works at: https://ir.library.louisville.edu/etd

Part of the History Commons

\section{Recommended Citation}

Buchtal, Henry, "A survey of the safety departments and their two main constituents, police and fire departments, in cities of from 250,000 to 650,000 inhabitants in the United States." (1947). Electronic Theses and Dissertations. Paper 1866.

https://doi.org/10.18297/etd/1866

This Master's Thesis is brought to you for free and open access by ThinkIR: The University of Louisville's Institutional Repository. It has been accepted for inclusion in Electronic Theses and Dissertations by an authorized administrator of ThinkIR: The University of Louisville's Institutional Repository. This title appears here courtesy of the author, who has retained all other copyrights. For more information, please contact thinkir@louisville.edu. 


\title{
UNIVAREICY DR LOUIOVILLE
}

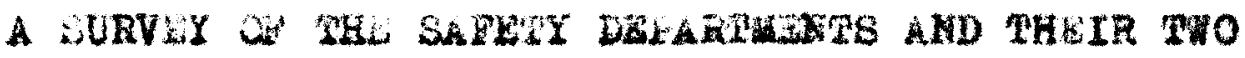

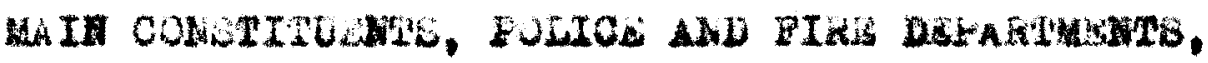
Il OITIE DE HROA 250,000 N0 650,000 IMBABIMATS IV Tha UKTIED SATEE.
\end{abstract}

\section{A D1ssertation}

Submitted to the Faoulty

of the Graduate Bohool of the Uatrereity of Loulsville

In Fartial tulfillatent of the

bequirements for the Degree

Je unster of Arts (or boinnce)

Department or H/STORY

By

Henry Buchtal

1947 
IAME OF STUDERT:

TITL UP THBSIS: "A survey of The Sufoty Departanta And Their Two Main Constituents, Police and Pire Departments, in cities of Prom 250,000 to 650,000 Inkabitants In the Unitod states."

AREROVBD BY RADITE COAMTTTSE OUWPOSED OP THE SOLLOING UMBER:

Rade of DiRnoros:

Dan: Lune 6,1947 
SURVEY OONAKS 
COMPBNE

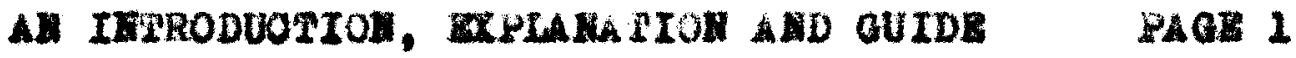

SURVIY AMALISIS, PART I, BSOTION I,

SABETY DSPARTUETST

PAGB 10

SURVIY ARA LYSIE, PART I, BROTION II,

TIRE AMD POCTOR DRFARTMLATS

PAGB 19

BURVIF IIIDEX ALD BRATIBTTCAL TABLBS

PART II, BROTION I, SAPETY DEEARTARATS PACS 43

SURVBI IIDEX AID STAPIETICAC TABLES,

PART II, SEOTION IT, BIRE DRPARTIETSS FAGE 53

SURVBI INDEX AND STATISTICAL TABLBS,

PART II, SBOTION III, POLIOE DERARTHATS PAGE 8?

IWRRODUCTIOA AWD BXPLABATIOR OF SPBOIAL

TABLAS ON InDIANAPOLIS

PAGE 129

BPEOLAL GUPPLEMGMRARY TABLE.

PAET III, PIRS DRPARTUBWT, IDDIA MAF OLIS PAGE 130

BEDCAL SUPYLSUEMTAY RABLE,

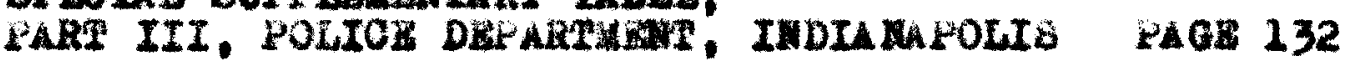

RABBRECE AND ADOTTIOKA BIBLIOGRAPHX FAOE 235 


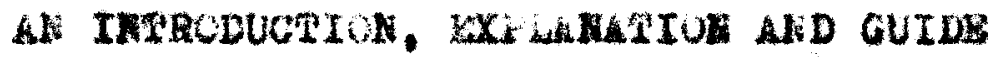
To TH: BUAVI 
The purpose of this survey is to ake -lear the plan, content, organization and work of public safety departments and thein two main subdivisions, Lire departionts axd polies departeents, in the United states.

All ofties withie the population olases of 250,000 to 650,000 ere canvased. There are atal of twenty-eight cities within that category. Of these, total of 15 olties replied fully or partially to the questionnalres. hunclpalities replying to all three sectlons of the burver were:

Blnelrghan, Llabana

Denver, Oolaredo

Louleville, Kentucky

8t. Paul, Hnaboote

Roobeater, New York

Cinolnuti, Onto

Columbus, onio

Toledo, Dinio

San Antonio, Toxas

Those muniolyalities replying to one or two sections of the aurvey, but not to three, were:

pakland, Galifomala*

Ind tanapolls, Indians

Row Orleans, Louistana

Dallas, Texas

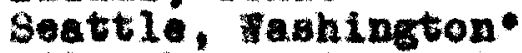

Hilwauke, Wisconsin**

-These altle do not have a publ10 safety department. PPartial unwere rocelved too late for induaton

within the tables. Anewer are in separate section.

- Miliwauke 's publle safety department does not - rabrace the ofty's ilre and police departments, and no answer was recelved from thea. 
CITTES RECEIVIWG QUESTIOWNA IR

squa

A labaina

California

Colorado

Georgia

Indiana

Kentucky

Louloiano

Hinnesota

Hiseouri

Nebraska

New Jersey

Now York

Onio

Oregon

Rhode IEland

renneaseo

Texas

wasington

isconsin
CIIY

Birminghan

Oakland

San Franc1seo

Denver

A trante.

Indianapol1:

Ious6v1110

How Orleans

Mnneapolic

st. Paul

Kanane Oity

Omaba

vareeg Oity

Howark

Buftalo

Rochester

Oineinnati

Columbus

Akron

roledo

portland.

Providoree

Memphis

Dallas

Boututon

San Antonio

Seattle

u1lwaukee
Aprox. popuLstor

280,000

325,000

650,000

350,000

325,000

400,000

475,000

525,000

525,000

300,000

425,000

250,000

325,000

450,000

600,000

350,000

475,000

325,000

265,000

300,000

330,000

275,000

315.000

320,000

400,000

275,000

395,000

600,000 
The population elgures of these oftes are purely approxinate. Thoy w111 be found highor than the 1940 census, beoause tistiates or probable increases over the past soven yeare have been added to the orliglnal census count. DLefarenees with the sotual number are belleved to be andl onough not to offect the unrvey.

Bach of the twenty-eight elties was cent a set of theee queationne1res, accompanied by the following letter:

(University of Louisv1110 Intterhead) *

Municlpal Department of Publio sufoty. City biall

Sixth \& Jertorson streote, Loulev 112. 2, $4 y$.

Gentlenen:

Under the ausploes of the Polltioal Selence Department of the Univeraity of Iouidville. I an undertaking coaparative eurves of the orgenization and function of varlous uniofpal

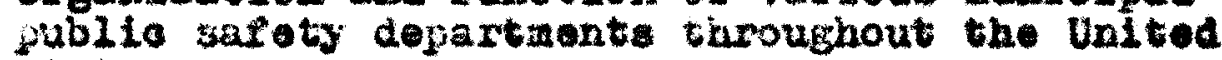
statos.

If you hav any printed atorial about your departinant, or eny division or office falling under its jurisdiction, I should bo very graterul to you for sending it to me.

Enclosed you w111 flad questionale which deals with the problene of publio eferety department. If avalimble publieations of your departant do not cover oveny question, please give proder and somplete answers to thote questlons in the nclosed questionnalre.

Youx proapt response w11l be highly appreolated. Thanklng you for your kind oooperation in this ttar. I reanin,

vexy respectrully yours.

(aigned) honry Buohtal

Teiplo copy of the lotter. 
The three questionamires, which way be found on the following pages, dealt with the eafoty departient itself, the fire departaont and the pol1ce dopartment. an attompt wee made to ollat all vital intomation about organization, function, Iinanelal scalea and personnel. Phis method was found to be the most wataractory in which tho wrvey could be conduoted.

The safety departaent questionnalro comtaino elght quastionis the ilre department questiondalre has 15, and the one for poltee departients has 17 gutetions.

Prom the resulte obtained, it ay be sald that little dificulty wa onountergd in ansering the questions. However, acmo oitios, bending only printec material, palled to chock on the completenese with which that material anewered the questionnaires. This accounts Pof the absence of some anemers in the tables. Mevartheless, the infermation roceived wa found to be sufejcient for an nalyois of survayod conditions.

Tho actual surves it divided into two parts. The first is an analysio basac upon the anawere recelved, and constructs the rinril rom suite, bringing out the nost important points whlch ecculed from the survey. This amiygls is partitioned into two sectione. Section 1 Poatures a comprebensive vlow of the executive 


\section{QUESTIONA IRE}

IN ANSTHERIHG QUESTIONNAIRE, PLEASE PRECEDE EACH ANSTER WITH THE NUMBER OF ITS QUESTION. PRONPTNESS IN MAILIHG COMPLETE ANSTERS WILI BE GREATLY APPRECIATED.

\section{SAFETY DEPAR TMENT}

1. What is the annual salary of the head of your department?

2. What are the divisions of its organization?

3. How many employees are there in your department?

4. Do you have a civil service (or merit system) for your department? Or any portion thereof?

5. What is the annual average appropriation for your department, during the past 5 years?

6. Is this appropriation made in a lump sum or is it nade in segregated aportionments? If so, how minutely is the appropriation segregated?

7. Does your department have an arrangement for salary increments geared to the cost of living? If so, does it function at this time?

8. Are fines earmarked for the Sinking Fund, or any other city fund? 
IN HISWERING QUESTIONTAIRE, PLEASE PRECEDE EACH ANSWER WTTH THE NUMBER OF ITS QUESTION. PROMPTNESS IN IHAILIIG COIPLETE ANSTHERS WILL BE GREATLY AFPRECIATED.

\section{FIRE DEPARTHENT}

1. What is your organization?

2. How many districts aro there?

3. Do you have a training school? If so, how is it organized?

4. That are the quelifications for joining your department?

5. How many employeos are there in your dopertment?

6. What is the salary soalo?

7. Hovt many mon aro assigned to an engino company, ladder company?

8. How many hours do your firomon work por wook, and what is their sohodulo of working hours?

9. Aro uniforms and fire clothos furnishod froa? If not, what are the regulations covering this perticular phaso?

10. Are mombers of your departmont organized into a union, indopondent or affiliated? If so, is union activity confinod to bargaining rights with the oity, or doos it include the right to striko?

11. How many firo stations are thoro?

12. That is their "looation plan"?

13. What typos and how many pleoes of fire fighting apparatus do you have?

14. Givo the avorago age of the apparatus.

15. What is your roplacomont schomo for old oquipmont?

16. What is tho avorago annual fire loss in your city, during tho past 5 yoars?

17. Doscribe your fire alarm systom. 


\section{QUESTIONAIRE}

IN ANSTERING THIS QUESTIONHAIRE, PLEASE PRECEDE EACTi ANSWER VI TH THE NURBBR OF ITS QUESTION. PROMPTNESS IN MAIIIJG COAPLETE ANSWERS WILU BE APPRECIATED.

\section{POLICE DEPARTUENT}

1. What is your organization?

2. How many districts are there?

3. Do you have a training school? If so, how is it organized?

4. Vihat are the qualifications for joining your department?

5. How many employees are there in your depa:"tment?

6. What is the salery scale?

7. How many men are assignod to the patrol section, detective section?

8. List all other parts of your department, giving organization, function and manpower.

9011 cemen
9. How many hours do your/anescox work por week, and what is their schedule of vorking hours?

10. Hre uniforms and arms furnished free? If not, what are the regulations covering this particular phase?

11. Are nombers of your department organized into a union, independent or affiliated? If so, is union aotivity conflnod to bargaining rights with the city, or does it inc lude the right to strike?

12. How many police stations are there?

13. What is the1r "location plan"?

14. What types and how many pieces of motor rehicles do you have?

15. Give the average age of your vehicles.

16. What is your roplacement sohemo for old equipmont?

17. Give statistics covoring crime in your oity, during the past 5 years.

18. Describe the polioe radio and call systam. 
funotions and organization of the andolpal publ10 actoty departeente and their work. It also Inoludes a flnanolal unalysis. The second section combines the andysts of the fire and police departments.

The entire analyolo 18 based upon the statiation reoplved from the eitio partielpating. Detalled reference is axde to the conplote otatiation tables, whioh oomprise the second pert of the survey. Furthermone, rootnotea mentionting other publioutlons, dealing with publlo safoty $w 121$ be found in the allalysis. A couplote blbllography, deslgned as a applementary culde to fuxther study, has been attachod to the aurvey. It is necessexy to state, however, that the andysis does not rely on outalde souroes. but concontrates upon the matarial recelved from the olt1es andwering the questionnalrea.

The weond part of the surver is a complete and minutely detailed group of statiotioal tables, which was uoed for the analyelo, and which liots wthin 1te three geotions the anowers to all quentions aked in the queotionnairen, erom every elty ansmering thas.

Each table deals ath a lngle question and gives the enewers to that question for each olty. The efties heve been arranged socording to the -2phabetionl order for the atates in whioh they ar located. The three sections of the second part of the curvey are 2 tables on safoty departuent answere received foxithe 16 questions 
on the fire depertment questlonralre and 17 tables on police dupartment anewers recolved for the 17 queations on the polloe departinent quest lonnalre.

Ench table, thorefore, 11ats one quetion and all olties of the survoy, with thoir answere to that queation.

Those tables whioh have not been analyted, alther oupplonent other tables which have received analysie, or they are self-explandtony and noed no ansisis for furthor clarifioetion or explanation.

The blbliography which is attached to the surver serves the function of being a list of references for further study of problems brought out by the survy, or to supplanent tho as feots which have boen listed and analyzed.

The axalysis has bas rainiored with focusing visi of particular problem of the Louisvillo Polles and Plre Department. These probleas which are not brought out in the anowex froa othar eltien patticipatiag in ths survoy, novertheless are an ald for the ovaluation of the survey.

Several recominendations for the Lmproveeent of the Loulaville Fire and folloe Dopartmots, based upon the survey, form the conclusion to the anaiysis. 
GECTION 1

SURVYI ARALYSIS

PART 1

BATERY DEPARTMETS 
Polle and Fire devisions are the basie units of public exfoty. Hiwavice "s stuation differs as 1 ts sefoty departinent 18 composed of a How Division, Trafele Division and a School Salety Division. '. Governaent unite oonoerngd with publio safoty in Dakland and ceattio function under the supervision of the local Olvil service Board. In exact opposition to this prectice are cextain cities which for 10cal regsons of econom and for the purpose of straaninine and connolidstion of funotions have lncluded within theis public safety departments the following bureaus, none of which is really related to afety departinent activities:

Bxolse, Clty Founds, Hadth, Parke, Playgrounds, Cenetarles, Bulldiags, Welfare, Social Service, Reform Sohools, Boxing and restine Comalesions - really a stato of function Charity Sollcltatione, and Smoke Abatement.

1. See table next page, or pout II, seotion I, Table 2. 
Birminghan

Denver

Loulavilie

5t. Paul

Bochester

Oincinnat1

Oolumbus
Pol1ce Department, Pire Department Po110e Dejertiment, Pire Department, Sheriff's Offlee, County Jall. Garc1ee Departinent.

Folloe Departaent, Pire Degartment, Department of Welight and Moasures. City Pound.

Bureau of Adninistration, Bureau of Police, Bureau of Plre Proteotior, Bureau of Pollos and Fin MInxw, Burouu of Hoalth. Buroul of polies, Burven of P1ro, pire and tolice Tolegraph, Buroau of Hoalth, Bureau of Parks, (1noludes plorground and cemotaries), Bureau of Buildings, Bureau of Traft ic Eng 1neorling.

Bulldings Conaission, Welfare Comisalon, Bureau of Sootel Bervice, dity Workhouse, Reform Eichool, Holice Departinant, Bire Department, Burean os M1 Provention, Bureau of Hakets, Fe1ght: and heasurés, Division of Comun1cations, Bureatid of trafflo Bnglaering, boxing and restiling 0omnission, Charity Solloitations Commission, Smoke sbatement Advisory and dppeal Bourd.

Administration Bureau, Bureau of Bullaing Regulation, Polioe DIvision, Hire DIVIBLon, Bureau of Ire and Police Comunications, Seoke hbotenent Division, Traftio Regulation end sngineering Division,

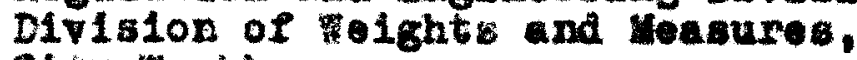
OL Wo rkhouse. 
Tolodo

San Antonio

Hilwaukee
Divialon of rollee, Ditialon of Pire, Division of butiding Inspection.

Divielon of Traffio inginoexing, Division of Safety raucation.

Home Division, Trafelo Diviaion, Sohool Safety DIvision.

All cities replying to the survey, except Ioulaville and columbua, have complete civil service for all divislone of thelr public sefoty dopertinents, 1.excluding, of course, exeoutive percontel. 2. Louisville's civil service act covere all employeas oxcept the Oniefs and Assiatant chiefs of Police and Plre, and the onlef of Detactivae. This is not a good situmion, and for the sake of efficienoy and adainistration, should be remedided. At one time, the above offleors ware under civil sarvice. political presure within the city and the state Asambily took then out. In Columbue the plature is not so serlous,

\footnotetext{
- Ban Antonio is unothor olty whioh does not lnolude dividions of pollee and fire within its safety departant.

1.800 part II, seation I, table 4

2.Se0 part If, Soction I, table 3

The table of anfety department divisions alll be found lin full datall in pert II, seotion $I_{\text {, }}$ Tho table number is 2.
} 
as only about ton men in the laborer quallfication classification axe not under oivil saxvice. Those, hoverer, should also be incluced. 1 . The Inp-ena appropriation precended the angregated aportlonwent. In many caece howerar, cisuce of fund: appropriated has $10 d$ to the system by which approptatione are epecifienlly wet alde for each detull of expenditure of operwtion. Th1s coteq, however, has 11tt1e flexibll1ty for energencles, whioh ocour very erequentiy in public afety operations. Whore weh segregated aportionmente are ade, it is advisuble to set aside a contingent or omergency fund whioh my aot as a reserve fox unforseen ovents.

O1ties baving the lunp-mus arrangement are: Birmingham, and Milwaukoe. All other oft1os which answered thi particular suxvey question have segregnted aportionnent aystem. It 18 not nocesenIIy true that luap-aun arrangenent leade to aloappropriation of funda. If proper afeguarda are taken and an woourate accounting and bookkeeplag arstem supervibes monotary aportionments, the luap wu ayoton oan work quite well.

1. Bee Part II, Section I, Table 4. 1.160 BnIth, B., Polloe gyetens In the United States, "political AfPote on adinistretion

2. See Part II, Section I, Table 6 
Only Denver, Louisv111e, Toledo and Ban Antonio do not heve an arrangment for balary Inereasenents or cost-ol-11v1ns bonuses out of all the olties replying to the safety departmont section of the survey. However Denver cranted a thirty percant salary increage durIng the war, and loulaville has wade several slight increases a.180. 1.

ith the excertion of Oakland, ealarios for the fority of nen amployed in the various divislons of public safety departments are very low. Oakland'e starting sulary for firomon is $\$ 3000$. O gear, the highest such lary paid anong surveyed oft1es. Inerements and bonuses are. therefore, of no great help to the anority of employees whose basic salary averages around $\$ 2500.00$ year. There are quite a few oitles which pay even lest. Iouleville $\$ 1950.00$, Columbus: 1920.00 , (an linorenent plan ralses this axount to 82160.00 in the fourth year) Cinelnnati: 31910.00 and San Antonio: $\$ 2040.002$.

It is interesting to note that sulary ranges, although they diffex at aturting polnts, develop into very sinilar ourve for the varlous claselflcations. This weans that increase fros one to

1. See Part II, Section I, Table 7

2. See "The Munlalpel Yearbook"

A. 1 teo tert II, section II, Table 5

Also Part II, Seotion III, Table 5 
enotbor grade does not diffor very moh in differont olties. 1 .

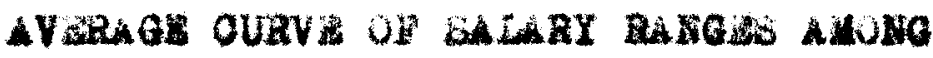

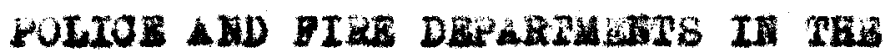
SURVRYOD OTIES

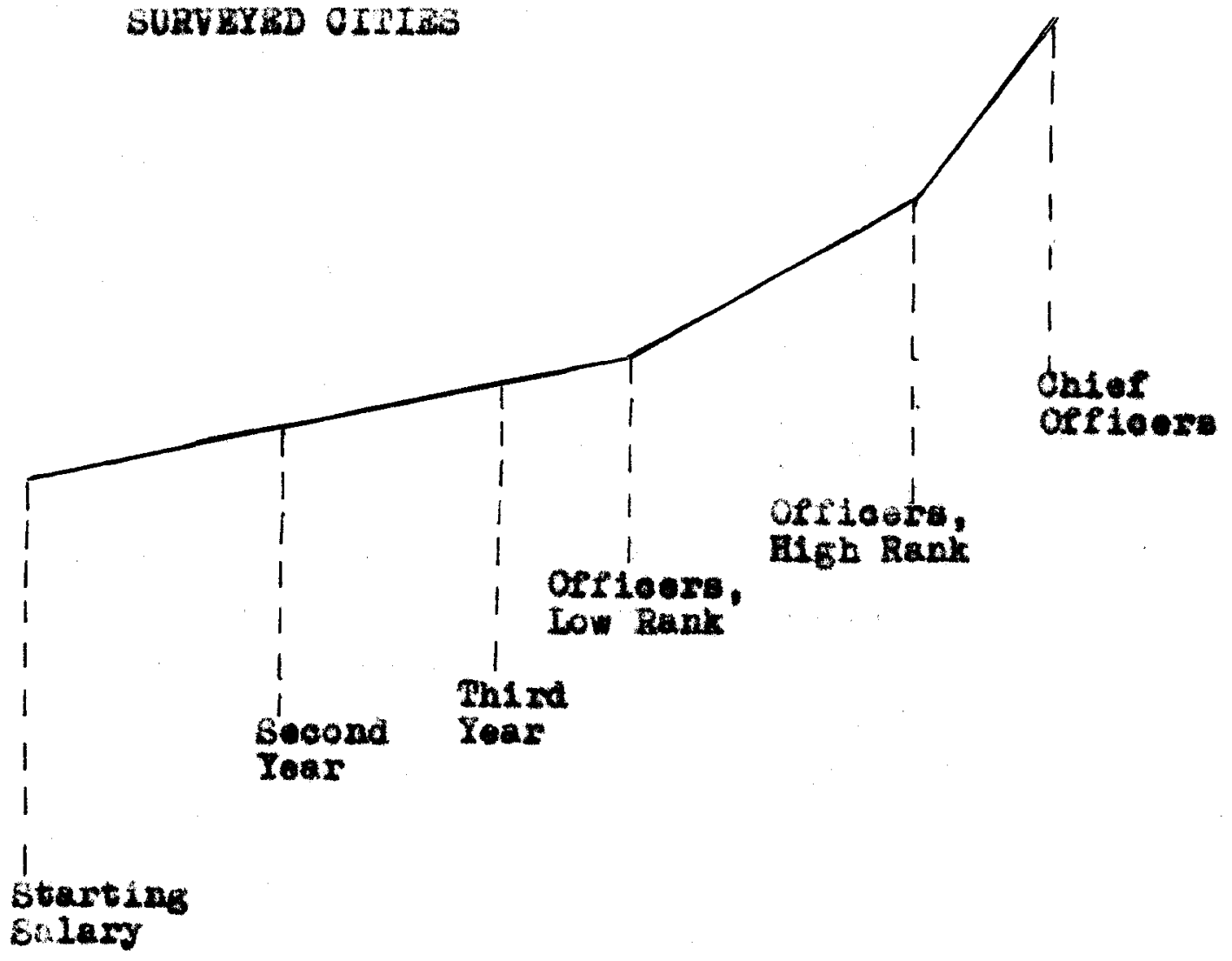

1. Soe, 21nk, H., Government of citien In The Untted States, "Tuñolpar Budgot". 
Wh110 inoremont plans are favosed over bonuses in most citles, emplogees generally frown upor a calluy plan based upon the rlse or fall in the cost-of-11ving. 1. This plan entails incroase in ealary wen prices are high, and cuts in eolary wher prices arop.

In generel a fixed selary is preferred by employeer to an elastio one. However, there is great enthusiesm about inoresent sohodules which hike waries certain amount over fixed period of y vars. 2 .

When the budget is arewn up for the flecal year of operations in Louigville, ceoh of the cepartment hesds confers with his excoutive officers and prepares a statement of neecs for hic depertment. These statement are then put together by the who in cooperation with his "cabinet" arswe up the budiget for presentation to the Board of Alderien. care 18 taken not to ask for moro than cun be expeoted to be dexived from olty revenues. The Director of sefety works out his portion of the budget in metings with the Chiefs of Pollee and Pire. Appropriations for these divisions are segregated Into two jor categories; Operation and ovorhend oxpentes, and equipent expenses. Thus, for Instence, $1 f$ the fire depactment intends to purohase five ine trucks in the now Ilscal yosr, attempts are made to set aside an adequate amount of money for them in the 1. Accoraing to employees in the Loulaville Plre Departaent. 2. nold. 
Safety Department. As the DArottor of bafety knowe epproximatily how wuoh mong can be apfroprieted for his department, bo must bo caraful to assign enfiolent funas for reoccuring and regular oxpenses, such as salarios, gasoline, to. These Iinitations often deoide whother now equipment wa bo jurahased or hew innovationa begun in the noxt flockl yoar.

1. According to statements from the Director of Bafety and the tayor's office, City of foulsyillo 


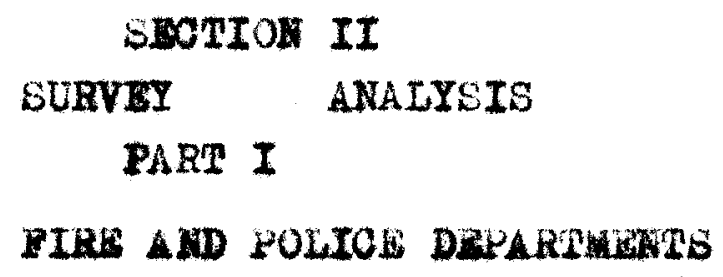


It is inportant to roalize in any analysis of polloe and fire protection forces of various municipalit1es throughout the country. that geoeraphle, coclal, economie, industrial and aven political differences and lnfluenoes shape diverse cities in diverse ways. 1 .

In soze ouses differences way be so accentuated that the only camon basib for anaiysis 18 the relationship of the munielpallty to the population 0lass in which the survoy was conducted.

These facts hold true, of course, in the matter of pollee and fire departaent distriots. The number of dietricts, thus, does not always deternino the size of olther the Iire-eightine or the pollce establishment. The number of fire Department districts range from 3 in wuch olties as Loufrvi11e $(475,000)$ and Columbue $(325,000)$ to 7 in seattle $(395,000)$. Polloe devartment dietricte vary even more. Cukland $(325,000)$ and Seattle (395, 000)have only three, while st. paul $(300,000)$ he 24 , Birninghan $(280,000)$ has 15 . Toledo $(300,00)$ has 13, and columbus has 102 nigtt districts and no apecific number in the daytime. Ho norm or gereralization is poaside in regarda to size or number of districts, ox-

1. Queen, S. \& Thonas, L. R. The C1ty "The Rise of Citias and Ubbanism". "Diatributive and seloctive Aspect of The oity". 
cept that in both fire and pollee departmenta, districts are senerally seclier and wore num- rous in the hesvily populated areas, and thet, while flre departments alway consider district to mon certain geographical area of a nuniclfality in which number of fire statlons are located, ushaliy under the cammand of - batallion or distriet onief, police departments vary in their concept of districts all the way from a siallar organization to that of the Pire department, to that of orulsing oar or walking beat, the latter, apparently belng the case in Columbus.

When it oomes to the question of pollce and fire atations, it is possible to raxer to standards set up by the National Bosard of Plre Underwriters, at leat in the sese of ire otations. The boarde he avalisble complete froil1ties for survoying and planning fire station locations for any munioffallt.. It lo obvious thet plan autable for horse-drane quipment, such as in Toledo and pertially in Luteville, 18 no longer adoquate for cosmunity in 1947 , no atter how 11ttle it hes changed since the horse-and-bugsy dey . $^{2}$.

1. See part II, Bection II, Table I, Aleo Part II. Section III, Table 1.

2. See Part II, section I, Pablea 10 \&1 
Pollee departments are not so fortunate a to have guardian angel Ilke the National Board of Plre Underwriters. Pollce stations, however, have undergono radical changer wib the introduction of radio and motor vehloles in polloe work. What holds true for their plen of looation, how over, does not 2lways oompare with that of the filre-rightine forces. A recent trend in polloe organization has tended towards complete centralleation of all tations into one oentral headquarters. This sy tem abolishes all precinot or district stations and dependis almost entixely on omising oare and radio. Louisville, st. Paul and Ban antonio operate uncier tals systat the present time. However, flaws in 1 t have alroady deveioped. Ioulgville, where centralization bes been infore for several years, w111 soon return to the old astriot station set-up, 1 . desplte almost 100 use of motor vohicles and of the most far-reaching and complete police radlo systems in the world. Loulaville pollo officials complain that oentralization impedes ooverage of eruiser and other betate in portions of the ofty which are far removed from hesdularters, desplte the radio racilities. When prisonere are taken, they must be brought to the central atation, and if it is several iles distant from the plece of arrest, it takes quite sone time for tho our to return to 1 ts beat. The same is true of shift changea,

1. Aooording to Louleville police officiels 
whioh necessitate great rush at hodacuarters, as all cars wut co there for the relieving of their orews. (steggering of shift changes has not helped the situation auficientiy to juetify contralization). Under the district stetion ayatea this will, of couree, not be recesBary, and cars w111 reasin in thoir districte even when the platoon is changed. 1 .

Manpower, a vital index is efiective protection, ahould be closely exainined in conneotion with the number of pollee departinent and fire department vehicles. Although cities difiar in their makouy and character, thore are certals. basic standardu of mpower. Municlpalities with population of eron 250,000 to 350,000 should bave approxiately 350 to 550 policeinen, the number inoreale lin the population, and depending to certain degree on looal conditions. Cities with population of 350,000 to 650,000 should have approximately 550 to 1000 policemen. These rigures are rough approximations based on gereral judgemente of police offlolals in Loulsvilie and Kow York city. 2 Thoy do not always it the conditionis of every polloe department, but at least constitute a nora. Thus, Loulaville, by admission of 1te own polloe officiale, has a

1. See Part II, bection III, Pables 11 and 12

2. Based on intervi with Hew York City pollce offleials. 
grosely undernanned pollce force. The total number 1s 484, but hould be approximetely 600 . Denver is also undermanned, having only 485 men. ${ }^{*}$

It is much harder to make any standurds for the number of police vehleles, a differont oltles have different standards. There chould, however, be enough motorized equipant to take care of several eargencles at the same tino, and still protect the city adequately. Equipment under the rigorous uses of today, and wth radio baking possible extensive cruising, should be put on definite replacement plan so thet no vebicle operetes more than two years. In this respect. Louisville leads the surveyed cities, with an average vehiele age of sx anths, while daxland (9 jears average ge), Coluabus 65 jaars average age). Toledo (6 yeers avorag age) and sectile ( $4.5 \mathrm{y}$ gar average age) could stand Improvenent. 2 .

Pire departmont etandards affer. This is becalue the number of nen depends upon the number and types of vehicles, and they in turn, depand upon the size and physical condition of the city. 3

1. See Part II, Section III, Table 4. 2. Soe Part II, Section III, Table* 13, 14, *15 3. So Bond, H. Pre Defenge "Bquipment stardarde" 


\section{4}

Acoording to the Natlonal Board of Pire Underwriters, engine companies should be maned by ainimun of 7 aen in the high value district, and alnimun of 5 in the residential areas. In two-plece engine comanies, the hose wagon should have alnimum of 6 aen in the high-velue distriot, and 4 men in the realdential areas. Laddex companles should have 7 men (aerial) or 8 men (eervice) in the highvalue districte, and 6 men (aerlal eervice) in residential areas. Queds nuet never be mannea below 10 men in the high-value alstricts, and 8 men in the $r$ idential ereas. These Plguree hold true for all platoons of ohifts.

It can be seen from this that the number or basic 11ro-fighting equipaent determines to - large degree the number of nen in a f1re departmont. The National Fire Prevention Association advisea that there be enough oonjantes in any olty with a population of over 200,000 to handle two large f1res imultaneously, and sti1l have enough equipment and men to proteot the rest of the e1ty. 2 where this is not

1. See Part II, Section II, Tables 4 \& 12, lso seo Bond, H., Elre Defenge, "Manpower"

2. Ibld. Conoult the Munlolpel Yosapook for further etatistios. Seo a.180, Governwent Doc., 0. M. Lire Series No. I 1 
possible - and the determination of this factor Lee solaly with the individund fire departants,the elty does not have adecuate elre protection. toledo may have enough equipment to protect 1ta property, but its distribution of only 4 men on all ladder and ongine companies is a dangerous gamble. It 18 extrealy afficult, acoording to the offleinls of the Louleville Pire Degartaent, to 16e portable $50 \mathrm{ft}$. extenvion ladder with a $65 \mathrm{ft}$. oounterpart of such a ladder with thet number of wen. If two $2 k$ in. hose lines are stratched from puaper to e Pire and the onginear 18 required to remin whthe apparatus, as is the case in most degartients, the remaining 3 men of a Toledo engine conpany would indeed have to cope with a superhuman job, whould any great amount of water pressure be applled. ${ }^{2}$

Acoording to the National Board of Pire underwiture and the Nalonal Fire prevention Association, fire-Pighting epparatus should bo replaced after maximus service of 15 years. If a plan cen be put into operation to apeed this turnover, so auch the better. With an arerage ago of 17 jears, St. Paul hes the oldeat equipment of oftles arewering the survey. Rochester and Dalla are just at the edge, both showlag

1. See part II, section II, Table 6 
an average of 15 years for thels equipaont. The best record is held by Columbus, ith an average of 5 years.

In the entter of training sohools, sust be considered flrst of all the adequacy of instruetion and pacllities. Toledo has ex exollent plan for tralning iti firenen, both at the beginning of their careers and while they are in the departant. A training tower la in service and operates under district chief. One wan from each of the fire stations attends arill for 8 hours dally, exoept Deturday and sunday Howerer, the only disadruntege in this setup 10 that durine the wintar anths the men must drill in their stations. It is always advisable to hove separete drill school bullding. In suoh a cas training way bo conduoted freely throughout the jour. Loulaville has such facilities, as woll as a full-tine drill water and asistant. Moreover, fter the initisl twenty-day course, men are given three days owah year for refresher courses and new methods. This however, should be inproved.

1. See Fart II, bection II, Table 13, also cee, Bond, R. Lire Defense, "Replaconent Standards". Roplies I On Indirmapoilo wo ro reoolved too late to find complete inolusion for analysis purposes. However, with an average age of 25 jears for equipaent, this dity tops st. Paul. See separate Indienapolis tables. 
Roohester's IIre college is adequately manned by 5 instruetore of that institution, and is the most conplete schooling unit ncountered in the survey. 1 .

The picture of polloe training is much brighter one, with excellent planning and facil1t1es in pructioally overy case. Running away with the honors, however, are suah oft1es loulsville where the ducational bursau of the polloe depart nt offers a lx-week course for recrults and has instituted refreshar group course of one weok cach, wth 15 en in oach group, rotating throughout the year. The New Orleans recrult training progran 1s oven more extendve, wth 350 hours of recruit trelning and a large number of expert Instructora. Tolodo, Dallas, San Antonio and seatilo have almilar setups. St. Paul, with no set progran or sobedule, seors to be in last place. 2 .

1. See Fert II, Section II, Table 2. Also see,

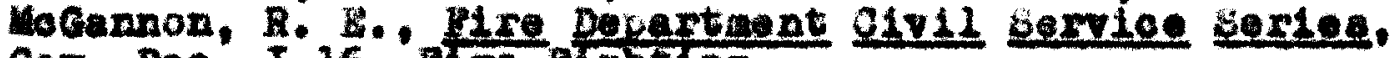
Cov. Doc. I 16, Plre Plehtios. Fubilc adainistration Service. Panplet No. 96 ActLon Por clties.

2. See Part II, Section IIT, Table 2, see 180, Snith, B., Pollce Syeters in the U. B. "Training". Gov. Doo. 110 Dopt. of the Intarior, Trainins for the polloe sentce. Aarioan tunrolpel ABeoc. Training Inforetion on Munlolpel Polloe: 
pulifleations for jolning the polioe and 1re depertmenta among oities of the survey show little difference between the two units. In flat, there re tow differenoes to be found between olt1es. All mublelpal1tios have specifloatione oonoerning welght, height, age, aducetion, mental and physical abilities and medical examinations. Age quallflcations run frow a low of 21 to 35 years in fire department standards. Helght and we1ght are alway put on a comparative bese and there 18 indeed so $115 t 10$ differenoe that separate 118 ting becomes unnecessury. The qualifications for polloe departmente are practioally ldentiand in every respeat. All oltles opecify oompllanoe with oivil service regulatione, whloh again are very olmilar in all reepecte. 1 .

Pire Departzent working houre are lso very similar in most elties. The most widely used plan 18 one of working 24 hours and being off duty the followirg 24. This schedule is in use in all olties exeept Rochoster, Toledo, and seattle. In Roohoster firemen work 5 dey tours (Ba.m.$6 \mathrm{p.sn}$, followed by 48 hours off, and then work

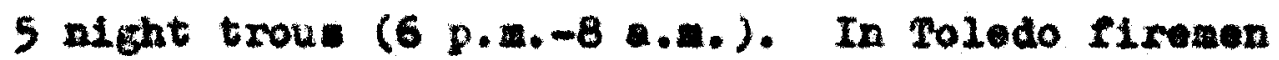
work 24 hours and then off for 48 . In Beattio the vohedule contalne 3 elght-hour ahifts in every 24. 21 of these plans, of course, mke nocessary a obift arrangement, so that the sume mubar of men always on duty. The manpower 1s almply 1. Bee Part II, EeationIII, Tabie 2, see =180, Snith,B.. Pollee Gratens in the U.S. "Training" Gov.Doo.116 Dopt. of the Interior, inciniteg for the pollee service,Aner-

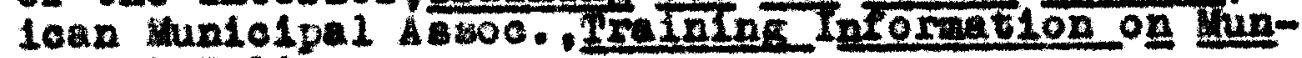
icleal polloe. 
divlded according to the sohedule. Although the alternating plan of 24 and 241 s tho noet widely used at present, firemen are generally preferential to the roledo plan of 24 \& 48. ecoording to sources in the Louteville Plre Depurtment.

Pollce working sehedules are ldentioal in all citiss. Although ahift change oocur at different times (ahioh is of no importance) the length of each shift, generally is 8 houre. 2 The survey how that while firemen are generally unlonized, euch organization has not yot spread quite so wldely anong pollcomen. Out of answers recelved anly Dellag and Ban Antonio huve no fire dopertment unton. The other cities are affiliuted with the A.F. of L. iscopt Roohoster, where firesen are organized into an independert asociation, known the pald Pirean'a Ald Absociation. The asociation' activity in addition to berglining rights with the eity, includes personal lozn assoctation for nember and atirement and desth benefit plen fund. Indianapolls, bestdes beling afflilmted

1. See part II, Section II, Table 7. Also weo By or, H.B. Salariog 늘 Houre of Labor in Mutelpel Rise Depertinente.

2. Section III, Table 8 
with the Intexnational Association of Pire Flehtere also has the Indiara Riresen' Association whioh is not affillated with any union. 1.

In pollce depurtient unlonizetion, the eurvey indicates that oniy Denver, out of all the oftes roplying to this question, has the A. H. of i. Police Union ae 1ts recognized bargaining agent. Loulov 1110 's yolicemen 18o have entered this union, but have not reecived reognition by the eity. According to the polloe chlef, 95t of the men belong to the independent pollee ABsociation of the Louldville Polloe Depertinent, which is recoynlzed a the bargaining agent, and aloo pays bick and death berefits.

It is not the purpose of this aurver to advocate of to oppose unionization of policemen and Iromen. However, the question arises as to why firemon are genorully orgen1zed and policewen are geberally not organized. Acoording to varlous muicipal officials there is four of divided athority on the part of eitios, when polloemen, who are eupposed to be loyal only to

1. See pert II, section II, Table 9 
their olty, and who, novertheleas, have been peraitted to organize. The riddle remaine. 1. Pire dopertment alara mystems aro almot 1dentieel in all cities replying to the survey. The camowell a lawe is ueed by all of them. Mamed after the firm which manufactures the equipwont, this systen conists of a notwork of Plre larm boxes, placed atratogionlly throughout a clty. Bach box bue different number and 1t olroult regleters that number at the 21 re alare office of the fire department by means of -lectric impulses. Whenever any particular box is pulled this process rebults automationlly. The fire alarm offloe then releys the box 81gnal numbers, which in turn regiater at the fire stations. Those stations whose quipment repyonds to the Mlarm, learn by the oignal number were the box is located. The entire process lasta no more than 15 seconds and is extremely efricient. Host Departments, however, baok up this alarm eyetea by inter-station telephono connections. Radio is also in use in Birminghan, Loulsville, Cinoinnat1, Toledo, Dallas and Beattle.2. Polloe comanications depend largely on radio systeas. Oakland, Loulev111e, Columbus and seatele have the ne: Y. M. transaltiers and reooivere.

1. See fart II, Section III, Table 10

2. See Part II, Bection II, Table 16 
Others are inotalling 1t. Loulaville, one of the ploneers in polloe radio commaications, was one of the very flret elties to have regular pollee rudio. Today the olty has the largest singleunit P. M. transaitter and gystea in the world. Loulsv 111 's polloe radio ha served as an examplo to many oitiea, and has even boen copled by Australian pollce departments. Louisville aleo ploneered in the ostablimbent of radio telegraph aystene, and 1 ts redio techniciane have developed an inviaible autenna for pollee cars. 1.

In order to obtain a clearer pleture of the Louleville pire and pollee departant aituations, It is wecesery to aention certain importsent facts which are $\mathbf{v}$ tal in the compllation of recomendations, besed upon the survey.

In the category of personnel, it should be pointed out that the number of exployees in the police and 11 ro departments of toulsville, 18 set by the olty ordinance, and degend upon the ava11able money for the Sufoty Departiont. At the present time, 353 aen are allotted to the Pire Department ${ }^{2}$ and 484 men to the Police Department. 3.

1. See Part II, Section III, Table 17
2. See Part II, Section II, Table 4
3. See Part II, Section III, Tablo 4 . 
4 number of annerntion ordinances have recently beon paseed by Loulsville. Should these attent to annox 25 square miles sucoeed. ther will be added approximntely 100 men in each department. 1. Dven before the annexation 18sue are declded, howevsr, the Director of Sefety w111 ak that betwoen 50 and 100 men be added In both the polloe and fire forces. 2 . This would alleviate an obvious manpower shortage which now handleape f1re and pollo work. 3 . The operations of the fire and the pollee foroes of Louleville are deened adequate by Ita Director of sefety, Chief of Pollee and Pire Ohier. All these offlelals, however. qualify that etatement by polating out that although all sorvicen are randered that can be oxpected in the line of proteotion and cafety, there are mon improvements that could be wade. ". These improvenonts consist, in part. of more intensive coverage of city territiony by police and fire forees, and nore reserve manower and equipent for omergenoy situations. 5 These

1. Director of Safety, City of Loulsville.

2. Ib1d

3. Part II, Seotion II, table 4 and Part II, Section IIf, table 4

4. Acconding to the Director of Safety, Ohiefe of Folice and 11re, City of Louisville:

5. Ibid 
Improvement are now being striven for, mainly through the plannod lnereace in npower, alreudy wontloned, and the purchase of additional nodern equipment. Ho need is seen for revising nothods of operations. All concerned are agreed that the methods and taotics used by fire and polloe foroes in Loulavills "are the most sdranced techniques possiblo". 1 .

Coxtain adninistrative functions of Louisv1110 Pollee and Plre Foroes are detarmined by state Law. Thlo series of loglalative acts provides in detall for certain activities of the police and elre departments. 2 por inatance. when oontliot arises in state Pire or police regulations with those of the eity, The state'd

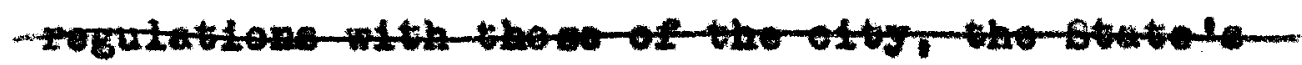
regulations - although they way be the arbitrary ceclations of an offlolel heving the power to ake than - muet take precedence over, what may in may instances be much sounder regulations put into effect by the muniolpal polioe or fire authorltias.

since the polloe offioers of Loulevilie cannot pructioally enforoe 211 of the law which they are supposed to inforce, they wust choose those

1. Ibid. The National Basd of pire Underwriters hes iso Informed the Ohief of the 71 re Departant that Loulaville's Pire protection system 1s satiafaotony.

2. Kentucky Revieed statutes, 95, $010-95 \mathrm{a}, 420$ 
on whioh the wost emphasis can be put. The power to wake such a cholee is a dengerous one, but the reeulte need not be bad if the public welfare is given first conaideration. The choloe is affected by certaln practioal conolderations, 1ncluding public opinion, and the activities of prodecuting officials, Judges and juries. It 16 useless for police to arrent offendere if the latter w111 not be indicted, proseouted or convioted. 1. Such police detection nothods the third degree are strietly forbldden and this probtbition 18 being anforeed oompletely. 2. However, the worale of the nen surfere enormously, becaube thelr activitios are homad in by excessive state regulation. The civil service at which covers both the polloe and flre departments infouisville, was weakened badis during the lest session of the state AsBerably when the Chief and Asistant Chiefs were taken out of the oivil service classifications. 3 This of course ald not help norale efthor. 4 another problem which faces any municipal fire and police depertments is that of interdepartmontal cooperation with parallel oxtramunloipal organizations of the same type. Loulev111. ' pollee departmont, for instanoe, ba an informal and unofflolal working armangement with the Jefferson County pollee fore, when it comes

1. According to the Director of Law, City of Louleville

2. According to Ohlof of Polloe, C1ty of Loulaville

3. Acoording to the Ioulavilie divil service Boerd.

4. According to employers of Louleville Pire and Polloe Department: 
to robberies or serlous eaergencies. Burthormore, an interdepartmental teletype syuten is in operation. Contect is a 180 maintained with tho Rentucky State Highway Patrol. This is again on purely unofficial basis. Information about major felonies and wanted persons is oxobenged betweon the two organizations. There lo pructiealiy no arrargenent with hew Albany and Jeffersonv1lle. Indiana. Cooperation is purely voluntary and very sporadic. Much oloser and more organized contact is malntalned by the Loulsville polloe Department wth the Pederal Bureau of Investigation. A11 fingerprinte and reoerde on felonies are exchanged with the I.B.I. An errangenent has been ade which enables the Loulsville polloe department to send to the $P$. B. I. Labortorles ang and all materials for analys1s, an tine. Duplloate flles are kept by both organizatione. 1 .

The fire department ploture differs slightiy. Until Jun, 1947, the Louiaville fire dopartment w11 respond to all calls for ald in Jeffereon County. This ba been done for many years, tho service being froe of charge. Contracts for fire ald are in foree with all ajor industrial ebtablishents in the county. These contracts apecify coll of servioe. Thus, if there is a llat service charge of $\$ 75.00$ for the first hour for each puaper cent. This rate drops to $\$ 50.00$ for

I. All Informationon poliae cooperation erom the Direetor of Sefety, City of Loulaville. 
succeding hours. The Battallon Ohief costs $\$ 25.00$ per hour. These contracts ill be volded when fire protection for the rect of the county ceases in June. This action is belng taken, partially to speed annexation ttempts, and also to save Loulsv111. taxpeyers the added and unjustified expense of providing ireo fire protection to extre-munie1pal areas. ${ }^{2}$

An unoffleial mutual-aid agreenent existe between the Louisville Tire Department and New Albany and Jeffersonville, Indiana. Ald ls provided mutually, on tri-city basis, whenever neceseary. Th1s service 10 so free of cherge and will be maintainod.

The Loulsille Pire Depurtment is a nember of the Netional Plre Protection Association and receives valueble informtion on techniques, function and organization froe this association. Tho departaent. furthermore, attompta to adnere as closely as possible to the standards set up by the kational Board of Pire Und rweiters, and coneults the bourd on all major changes. There is also unofficial and voluntary, but very effective cooperation between the Loulsville Pire Department and the Kontucky state Piro Marshal's offlce. The State Bire Marshal's orgenIzation is an inspeotion and advidory service of the state. 2

1. Acoording to the D1rector of Bafety, Chief of the Pire Departwent, and Director of Law, C1 ty of Louieville

2. According to the Chief of the Fire Department, and Chief of the Mire Frevention Burean, dity of Loulaville. 
It w1ll be profitable at this point, to wake several comparisons of Louisville with other clt1es. A tar as fire los is concerned, the per capita cost to the poople of Louleville ls the lowest of all olties aurveyed. It stands at $80.91 \% 4$. Comparing this figure with cincinnati, eity of staillar size and in einilar location, we lind the per oppita fire lose in that muncipality amounting to \$1.8954. Dallas, city whioh a.180 falls lato the asmo population category and which is lese beavily industrislined, has per ouptta fire loss of \$4.1944, the highest among surveyed oities. As far

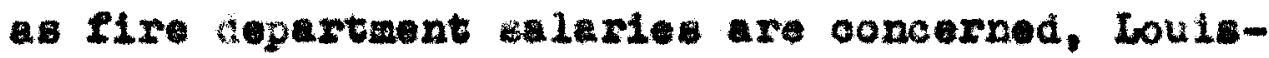
v111e does not fare so we11. In fact its starting walaries for firemon are the lowest of all surveyed

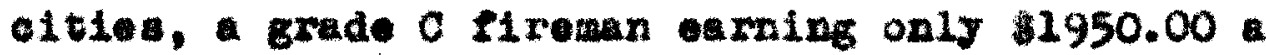
yoar. Oakland, which le smalar ofty than Loula ville pays the highest 2ire depertment salaries of surveyed clties. I flrst yoar fireatan in Dakland carno 3000.00 per annum. 1 .

In oomparing the number of serious of recorded by the Loulaville Bollee Departent for any of the past five yours with those of other yolloe departwents of the surveyed cities, we find that Louleville has modius poeition. por insterce, there wer 9488 serlous offerses in Loulsville in 1945. while Cincinuti reporte 8128 for the ane year. The highest number of offenses of aerlous nature anong the ourveyed cities is found in onklaxd, which reports 121,423 for the your 1945. The 
Lowest number for that partioular year was recorded in San Antonio, which had only 5043. San Antonio however 18 a much taller efty. As far a pol1ce lary comperison are conoerned, thoy 111 be found identionl with those of the fire departmants. 1. Thus, Loulav111' 's pollowan make only 31,950 .00 yoar, again tho lawest salury for the lowest grade amone ourveyed olties. In comparison, Oakland's eirst year patrolmen make $\$ 3000.00$, the highest salary anong surveyed olties. Complete ldentity with t1re depertment salary ranges for enoh oity will be found. 2

Ihen we compare the per caplta cost of public eafety depertmont operation in the surveyed cities. we find that Louluvilie is again the holder of the lowest cost bracket anons surveyed oitles. Loulsville's per cepite cost umounte to 4.6865 , while St. Paul registers with 6.7266 . Rochester leads the parade with the higheet per capita cost of $11.9395 .^{3}$

1. See part II, Seotion II, Tables 15 and 5

2. See Part II, Seotion III, Tables 16 and 5 Al arveyed cities use P.B.I. Inoident classification. 3. Dee Part II, Seotion I, Table 5 In Pairness to Bochester, it should be polnted out, that the high per caplta cost of the operation of 1ts safety department may be oaused by including the safety departsent certein bursaus whioh are not normily art of publio safety departinent. 
In concluding this analys16, it asy be profitable to list recomendations for Louleville's police and I1re depurtmenti. These reocmendations are besed upon the ineoration contalned in this survay. 2. Civil Bervice

It is secosmended that all anployee of the two department $s$ be put under the present set-ug of the Louinville civil Bexvice and Merit syatem, and thet no abe be excluded from its protection. As the layor bas the power, under the present set-up, to appoint anyone ho places to the postion excempt from the Oivil sexvioe protection, it is necessary that those ofrlces be returned to CIVII service. Otherwise there 18 the distinet danger the completely inexperienced individual my, through politioal influenoe, beeone executive of flcer (non-polley making) in an organization which demude full exparienoe for proper sunctloning.

2. Menpower

It Is recomended that the Fire leperteont contain no 1060 than 600 and no wore than 700 mon.

It is recommended that the Pollee Departeont oontain no lese than 650 and no more than 750 men. These IIgures are besed upon averages computed from the aurvey tables and are in accord with manow doma judged to be surtilelent by Loulavillo police and Piro authoritios.

3. Equipment

It is recomended that the rise Depertant oontain no less than 30 ongine companies, 15 of which 
should be two plece companies; no 1088 than 25 truck or ladder companies, of which 7 or 8 should be aerial ladder trucks, 4 of which should be $100 \mathrm{ft}$, aeriele, the rest $85 \mathrm{ft}$. arials. The quad companies should be discontinued and roplaced with city uervice compales. There should be no less than 3 chemical trucke and two water towers. Where should be put in service two floodight and smoke -jector truoke and two energency resu truoks. The number of ofstriote should be ralsed to 5 , with - corresponding number of Batalilon Chlofs.

It 1s recommended that there be no less than 75 orulsine care and no leBr than 25 patrol-ambulace trucke in the pollee Department. Furthermore. motorcycles chould be replaced by antomobiles for traffic duty. Motoreycles axe far too dangerous to justify their additional sped and meuverability. Districts should be reised to 5, with a corresponding number of Captains and equipmont. 4. Salaries

It is recommended that salary acales in the fire and pollae degartmento begin with a minimum of $\$ 2500.00$ for arede 0 privates or patrolmon. There should be a corrosponding rise for higher gradeg in both defertaents. These figures are based njon approx1as te everages computed tron the survey tables and are in accoxd with salary standards rivisloned by the eaployees of the Louisville Ilre and police departimenta.

5. Extra-munielpal cooperation

It it recomended that the pollee depsitment 
establish complete autual ald and information Eervioes wth the Jefferson County Polloe, the Kentuoky state Highway Fatrol, the Jafferoonville and Hew Albany pollee Departients and the Indiane State Hollce. Fixed nnual feos for 11 governmotal units conosmed in these servioes should be druwn up on contractual basia.

It is recomended that the Loulaville P1re Departmont astablish complote mutuel id cervices with the Jefferson County Fire Depertuent, the How Albeny and Jefrarsomille Dre Depertment and the Kentucky state Dir Marahel's offleo. Fixed annual fees for all governastal unlt conoerned in these services should be drawn up on a contractual basis. 
suonor I

SURVEY INDLX AKD STATIBITOAL TABLES

YART II

SAERTY DEEARTARESS 
Table 1

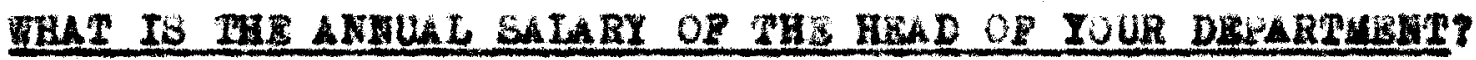

ATABAM

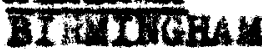

CALIPORNA

OAXJAND

COLORADO

Dostritere

KWDUCK

Dobror Luts

LOUTSLAKA

IET OKLEK

ATIKDSOLA

ST. BhtL

Nat rok

Fothsthe

onto

OTWETKEA II

0 LUABUS

TOLED

axds

DALCAO

BaA AHTHIO

HABATNGTON

Buthiter

* ISOONSIN

BI LNaUXa
$46,676.00$

akland does not have publlo fety department.

4.000 .00

5.000 .00

Safety departient anewero not roesived.

4.500 .00

$\$ 7.500 .00$

$7.500 .00-10,000.00$

$5,400.00$ plus $10 \%$ for increased cost of livins. 8.000 .0

Sufety Departmant not received.

3.480 .00

Sosttlo does not have a publio safety department.

$5,000.00$ 
Table 2

WHA ARB THE DIVISIONS OR IOS ORGANIZATIOE?

A.CA DAM

BIRXIKOKA

Pollc: Departaent, Piro

Department.

CA ILCRNIA

OARTAND

Oakland does not have a public safety degartmont.

COLORADO DATV VIE

Polloe Departinent, P1re Dapartment, Sherifs"s offoe. County Jail, Bxoise Dopartwente.

CEL UCKY

LOUISV LWW

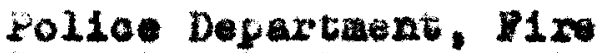

Department, Department of Teighte and Hoasures. olty sound.

LOUTSIA UA

Wh OHLARS

Safety depertaont not recelved.

4TXNa60

BT. 2atL

Bureau of haministration, Bureau of Folles, Buratu of P1xo protection. Buraau of lolloe and Pire Alaria. Bureau of Health.

KST YORK

TOCHESTER

Buxteu of pol10e, Bureau of

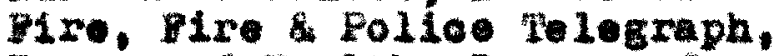
Burasu of Hoalth, Bureau of Prorke (1naluded Pleygrounds Centerios), gureau of Buildings Burosu of Traftic Nriginexing.

OHIO

FIVIWKAII

Bullaing comels ston. Peliare Contsion, Burean of Soolal Selvies, C1 by Norkhouse, Reform Schoole, Polise Departinent, Pire Departant. Buraau of P1re Rrevention, Bureau of Maricts, Melghte \& Magures, DIvision of Conmunlcations, Bureau of Prafl to snglneoring, Boxing Wresting Comatiolon. 
Table 2 oont't.

onIo

WIWOINha II( Contimued)

COLUMBOS

TOLEDO

I 6448

DADTAS

Bav anONIO

VASRILOROL

SHATIL

T60uts IX

TILAUKW
Chantty solloltations ConAlssion, Smoke Abatament Avisoxy a Appal Board.

Adninistration Bureau, Bureau of Bullding Regulation, Polia Division, Rire Divielon, Buraan of tra Pollo Commanicatione, Smoke abatoment Diviaion, Prafile Regulation a taglneering Diviston, Division of elghts 8 Heasures, O1ty Vorkhouse.

Diviaton of Pol16e, Division of Ira, Division of Bullding Inspection.

Satety departant andwers not recelved.

Division of Traftic anglnerint, Division of Salety Bucation.

Seatrle does not have a publis eafety departaent.

Hone Division, Tratelo DLviaton, Sohool Safety DIviston. 
rable 3

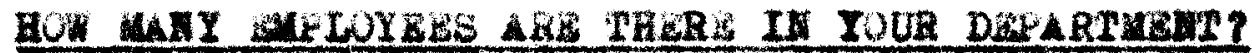

A LABAMA

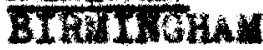

GálPURATA

OARTAKD

COLARDO

Diminer

REmUCKY

LOULSVILUE

LOUISIANA

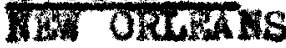

Wh: YoRX

ROALSTLR

OHIO

CInCInkat

COLUABUS

TOLADO

TaXAs

DACTS

San ANDONIO

VASRIUGROY

Spkituth

W IOCONSII

TILAG UKRE
3 (Administrative only)

Oaxland does not have public safety departaent.

Answer not clear.

3 (Administrative only)

No afoty degartmont answers recelved.

1556 (Inoludes all bureaus and divisione)

This question not wnwered. 3 (Adninistrative only)

800 (Includes 11 bureaus and divisione)

Sufety depertmont answers not reeolved.

4 (Administrative only)

Seattle does not have publlo safoty department.

6 (Adminietrative functional. as this depertment does not inolude the usual subdivisions of lire and polloe, te. 
Pabl $\bullet 4$

DO YOU HV VE A CIVIL SRVIOE (OR URRIT SYSTEY) POR YOUA DEPARTIGYT? OR AEY PORTION FHERSOL?

AL DS4a

BTRMTRorau

CALTEORLIA

ORLIAW

COLOLADO

DEWVAR

Cartuar

WUISVILL

LOUTSIANA

1EV ORLEA

YTINESOA

3r. $\mathrm{RaVh}$

14. YOR

ROCALSTM

OHIO

OTHOImALI

OOLUMTES

POLSDO

TKxas

DALTAS

SAN ANTOKIO

OABISCTOX

SHATISW

TSOUNSTE

IILA URR'
OLVL1 Sexto

o1v11 Bervieo

a1vil Servio

$01 v 11$ service ror polloe and Dire Depts. Ohiafs, Asbidtant Onleta and tolloe Oapt. of Detectives excluded.

Ho cafety appertmont answers reoelved.

OLI1 Servise

O1v11 Berv10e

C1vil servioe

CIVI1 service exopt labores clasaliloation, approxinately 10 anployeas.

C1v11 Bemiee

No Safety departaent ansurere recelved.

O1v11 Servioe

Seattle does not have pub110 sefoty depextment.

Civ11 semiee 
Table 5

WAT IS THB AMBUAL AYERAGE APPROPRIATION POR TOUR DERARTUENT, DURIHC THE PABT RIVE YEARS?

ALABAM

BIRINCHAM

CALTPORAIA

OAKLARD

COLORADO

DKAVBat

Kafury

Woutsintew

LOUTSIANA

DWW ORLEATS

ITKNEOTH

ST. PAUL

Leil TORK

ROAWOLER

ORIO

CTRO IIWATI

Columbus

TOLADO

PLXas

DALERS

34 ANTONIO

ASH IMGRON

BEATTLE

ToONSII

IIthinge
Fol1ce, approximately $\$ 739,000.00$ Fir., pproxiastely $866,600.00$ Far capita: 5.7345

Oaklend does not have publlo safety departme ot.

\$87,000.00 (Barety department administration only.)

$$
2,226,105.00 \text { fer ouplta. 4.6865 }
$$

No sufety dopartment answex recelved.

2,017,993.00 Pur capita: 6.7266

$4,178,839.00$ Per cap1ta: $\$ 12.9395$

Th1 question not answered

$\$ 2,000,000.00$ Per cep1ta: 6.1539

$2,119,000.00$ per ceptit 7.6333

No safety departient enwers recelved.

This answer not reoelved.

Battlo does not have a publio salety department.

30,000.00 (Safety department adninistrative only) 
IS THIE APRROPRIATIOA WADE II A LUME SUM OR IS IT

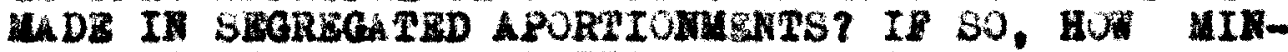
UTELY IS THE APFAOPRTATION BLCREGATED?

A TABAMA

BIRMINGHA

CALIRORLIA JAKLAR

CULORADO

DeNVIa?

XETPUCKY

Totrsvith

LOUIS TANA

TEM ORLEAXs

MINESOOA

BT. PAVL

ALT YORK

ROCARESTH

OHIO

CANCINKA

columbus

TOLEDO

TEXas

DALEASS

BAN ANTUNIO

WASIMONOS

BEATHLE turp sun.

Oakland doos not have publie safety departaent.

Classifled and ltenized

Classifled and 1temized.

No safoty department answers recelved.

Separate lump sum eppropriation made for each bafoty depertment division.

Separate lung sur appropriation made for each safety dopartmont division.

Classifled and itenised.

clasalfied and itemized.

Begregated eportionments divided into wonthly needs.

No safoty dopartiont answers recelved.

This question not answered.

Seattle does not have a public safoty department. 
DOZE YOUR DEPARTUBH HAVE AN ARRATGEMSNT YOR SALARY

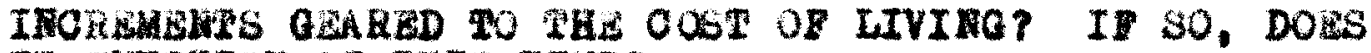
IR BUEOTION AT THIS TIER?

ALSBALE

BIRIIAHA

OALTDORUIA

DRLAD

OOTORADO

DFATER

CHAYOKX

10018V1Lits

LOUTS TAKA

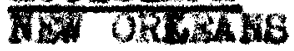

MIU $000 \mathrm{MA}$

BT. RAUL

Win YORK

ROCKESIT:

OHIO

OININRA

CoTUMBUS

TOLBuO

WXAS

DhLtato

BAN ANTOETO

YASA ITOCON

BRATrtes

HoconsIA

MILWAUK HE
Ies, Determined by Givil service Board.

Oakland does not have publio safety aepartiment.

Mo. However, a 30\% inoroase durlng the last war.

Ho. However, several very slight Inoreages huve bean nade in the past fon yours.

No safoty department anowers reoelved.

Ies. Ios.

Yos. Yes.

Yes.

Yos. No.

Wo.

No actety department angwers reeseived.

No.

Seattle does not have aufety departinent.

Yos. Yos. 
ARE IIMES BARMRRD BOA THE EIMKTMG ZUMD, OR ANY ONHER CITY MUND?

\section{ALABAM \\ EIfrimotan \\ GALIBORNIA \\ DARLALD \\ COLORADO \\ DisWrar}

RENPUCKY

EOURSVIHLs

LoUTSInkA

IBW ORLaR US

MrWNOSORA

BT. PAUL

EVT YORK

ROCHEDTR

OHIO

CTWCInLA I

COLUMBUS

TLEDO

saxas

DA titas

SAN ANTONIO

MSHIN TON

BEA TILE

ISCONSII

DILAOLES
Ko.

akland does not have public eafety department.

Pines go into tho city General Fund.

Pines go Into the slaking Pund.

No safety departient answers received.

Pines go into the Otty Ceneral rund.

Some fines go into the Pire and Pollce Fension Punds.

No answer to this question. Fines go into the Clity Cenerel Fund.

no.

No safety department answers received.

Pines o into the City General Fund.

Seattle does not have a publio aafety departaent.

Pines go into the City Generval Fund. 
53

\author{
SEOTIOE II \\ BURYEY IUDEX AND BMA RTSTIOAL \\ TABLBS \\ PART II \\ PIRE DWHARMGWTS
}


Tabl* 1

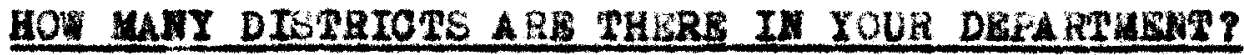

A L Bama

BTRLIOHA

Pour

QALIPOBKIA

OARLALD

Six

COLORADO

DEWVAR

Ire

cennuoky

Iovisvitus

Three

LOUIBIARA

TEX OALST 18

No 1 we Department answers rooelved.

$M I H N E S O R$

ST. PAVL

Pive

Hari yopr

ROCTRSTER

Bour

onro

OTIO ImRatr

S1x

coluaros

Three

TOLISDO

Four

TSXas

DALIEAS

Seven

GAN ANTOMIO

Four

MASINCROL

BSATILE

Bive

4 ISCONSIS

TISAMUKE

Ho Ire Department andwers reovived. 
DO YOU HAVE A TRAINTMG SOHOOL? II SO, HOR IS IT ORGANIZRD?

\section{ALABAMA BTainchay}

GaLIPORIIA

DAKTWAD

COLORADO DEIVEH

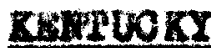
LOULSVILU

LOUTSTANh It) JRE Ans

IITHesora ST. PIOL

MED YOAK

BOCLESTIR
Yos. Under direetion of chief Brill Haster and Company officers. assisted by vocational instructor.

No.

Treining is oonducted by a Drill meter going into oroh dietrict and conducting evolutions and loseone.

Yes. The tralning sobool is undex the oupervielon of a Drill Master who 1s seaisted by an Assistant Dr1 II Master. All now reoruits are given twenty day course of 1nstruction in Fire tighting, reecue work and the use of fire fighting toole. All fire oompanies are cent to regular conpany drill sehool for three day each year for information and tralning on the nowest methods of fire fighting and rescue work.

No Hre Dopartmont answers received.

Yes. The sohool is operated by an inetrictor. orfloers recelve training four times year and the drill tower is in operation during the cunen. In winter training 10 eupervised by District Chiefs and Captains at tholr quartere.

Tes. The Rochester Mire College has one Deputy Ohief as Director, one Ch1ef Instruotor a Assistent Dir ectar, one Battalion Chier as tamual Training Instructor, two Pirenen as Instructors. 
Table 2 cont'd.

OAIO

CAC DNATI

COLUMBUS

TOLESDO

TEZAS

Dhitias

SAN ANTONIO

ASRTYGTOE

BDATETE

ISOONS TH

TIWh Ux as
56

Yes.

Yes. Under the supervieion of a Captain.

Yos. A Training Towor is in aervice and operates under a District Pire Chier. One an from each of the f1re tations atteads the Drill Tower for 8 houre dally except Saturduys and sundaya. During winter months drille are held at the stations.

Yos. Under the eupervision of the Department Instruetor.

Yes. Sponsored by the State Board of Bduc ton.

Yes. Oreanized on the basis of battalions and companiea.

No Plre Depkrtment anewers received. 


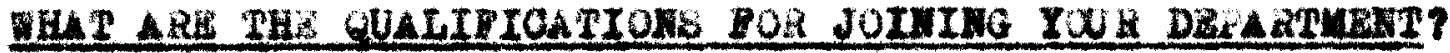

ALABAHA BIRE TIOHA

QELIEORWIA

OUTORDO Datien

Gancuor DOUISVILLE
White. wale, oltisens and votere of the ofty of Birainghen, Aget 21 to 27. He1ght: $5^{\prime 8}$ " to 6.4" "Welght:140 to 230 pounds, in proportion to helght. Bduoation couivalent to graduation from atandard high sehool. Must pass medical and physioel exas1nation.

Pive year resident of the of ty of orkland. One year if veteran. Complote phycloal exarination. $\mathrm{g} 11$ ity teet. Nritten oxamination. Oral interviow. Record invertigation by Inspectore of the rol10e. one year on probation afver appointment.

Candidates must be United states oltizene, one year resident of the C1ty of Demver. Helght $5^{\prime \prime \prime}$ to $6^{\prime \prime} 2^{\prime \prime}$. We 1ght 137 to 230 pounde. Hust paes rlgid mental and physlcal oxamim tion in additionto medioul exaination. Thoroughly investigated as to reoord.

Applicants nuet be between the agee of 21 to 35. Thoy must have high so mool education. Height $15^{\prime \prime} 7^{\prime \prime}$ to $6^{\prime \prime} 5^{n}$. We $1 \mathrm{ght}$ 145 to 250 pounds. Welght acoording to hoight. Suet pass written, phyelcil It nes, oral and nedical testic. lust undorgo work record and character 1nVotigation. Fallure in any phase of the exanination nay be grounde for the Louteville Oivil Servioe Bo ad to declare the appliant an fallns in the extire oxaniration. Applicants nuet be c1tizens of the Unitod States and must furnibh to the Loulavill olvil semioe Boman $u_{1}$ or denand, proof of act, cltisen ahip. xparienoe and educational qual1fications. The decision of the aedlesl exaniner conotralat the phytoul condition of the applicant shell be Pind in all cages, unleas revered by unanimove dectsion of the Board. 
Lourbrata Mat OrLisa

MIKHESOPA 31. PAUL

MGI TORX HCLESTRR

OHIO

CTre unkar

coturabe

Tulabo

caxas

DW LLAOS

BAN AFTOETO
No pire Departaent answers received.

A11 appointeonts are made Iroa Oivil Servioe eleglbility lieta. Applicarite must be quelifled votere of the elty of st. paul. under 35 yeare of age, not less than $5^{\prime}$ " In $^{\prime \prime}$ height and of a corresponding minimon and maximum weight as presoribed in welght schedule. Applloants mut pase a sedical. physioal and writton examination.

Applleants must be botween the ages of 21 and 29 . Height $5^{\prime} 7^{\prime \prime}$ a inimum. Froe fros such influmItIes are preceribed by the Civil service comalesion. Hust pasa phys10a1, montal and athletic teat.

Ho answer to this quation

Age: 21 to 30. One year resident of city of Coluabus, native or naturalized United states oftizen.

Age: 21 to 31 . Wo1ght: 141 to 220 pounds aceerding to hilght. Height 5'7" to 6'3".

Civil Service (City) certiflcation. Age: 21 to 30 . Two y wars high school. Ginimum weight: 149 pounds. uniman hef ght: 5'8". Phyeically fit.

American eftizen. Age 21 to 30. qualifled under civil Berviee. 
pablo 3 continued 59

Natragro: SBsitite

United states oltisen. One year resident of the oity of seattle. Hinimum holght: $5^{\prime} 8^{*}$. Age 20 to 29. Appllant must bo of good moral character and phyolcaliy abla to perfor the dutios of the position.

TSOUNE IX

IITERUKRE

No Flro Departuent answers reotred. 


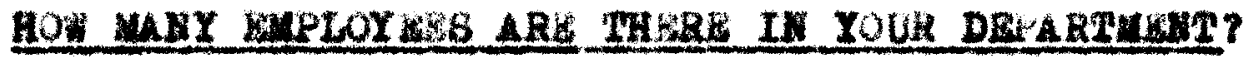

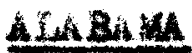

BIMITroray

OALIVOHL

OnNGLD

OUTORADO

Detrivat

SOMOOLX

DOUTSWILLE

COUTSIANA

WW ORLEANS

IINA $200 \mathrm{PA}$

BI. PHWL

HEY $\mathbf{Y O X}$

ROCHESTHR

Ouro

Sunnwa

outrurovs

NOLEDO

TEAS

DA Lhas

SAN ANTORIO

ASHLOCON

SBATLIE

TSOOLSTI

TIIX L UK
320

465

425

353 (oporating wth 49 vacanoleb)

No I1ro departaent anumere reoelved.

349

554

709

340

404

590

391 (opernting with 40 vacanoles)

609

Do Ire Departaent answers reeclved. 
Table 3

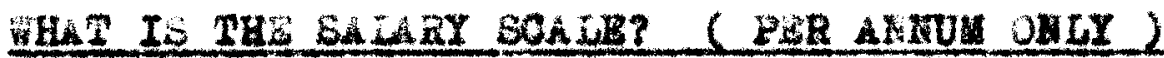

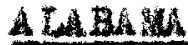

BIfuTrokn

Ohief
Assictant Chief
Battalion chief
Oaptain
lieutenant
Driver
Pire Fighter

5652.00

4260.00

3660.00

3300.00

3000.00

2760.00

2660.00

Coliromia

\section{DALCWWD}

GOLORADO

DEWVER

\author{
Ohier \\ Mrst Ab81stant Chief \\ Becond Astetant ohier \\ Battalion Chief \\ Guperintendant of \\ Eng 1 nes \\ Captian \\ Ieuterant \\ ne 1 neer \\ Chice" Operators \\ Hobeman 3rd. year \\ Losenan 2nd. year \\ Hoseman 1st. you
}

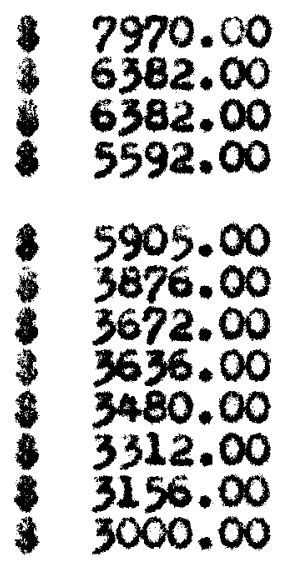
Onler
Deputy ohief
Assietant obter
Superintendart of
Plre-A Lax
Secretary
A celstant superinten- dant of In-Alara
Hacbiniat \& Hneman
Captaln
Buglneer Lutenant Prat arade Piroman a Operator
seoond crade Hreman
Third Grade Firensen
Pourth orade Pireman


KELIUCKY

Dotsvitio

onlet

Assistant ohlef

Battallon Ohier

Oaptain

Lieutenant

Engineer

Pire Alaxu Operator

crade A Preman

Grade B. Plrowan

Grade C Piremen

Intepectox

Secretary

As intant booretary

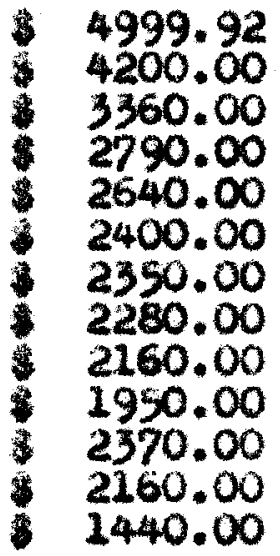

LOUISIANA

IBT GrLEAns

No Pire Department answers rooelved.

IINS6OTA

BT. PLUL

112. TORK

$$
\begin{aligned}
& \text { Chief } \\
& \text { Assietant Chiet } \\
& \text { Distriet Chles } \\
& \text { Captains } \\
& \begin{array}{l}
\text { Bogineers } \\
\text { Birefienters Ohauff- } 2575.40
\end{array} \\
& \text { eurs } \\
& \text { Pire-prevention Inspec- } 2503.20 \\
& \text { tore } \\
& \text { chler pire-Prevention } 3454.60 \\
& \text { seeretary } \\
& \text { Inspector } \\
& \text { sarietant Ohi of Mire - } \\
& \text { Prevention In - } \\
& \text { opector } \\
& \begin{array}{r}
6000.00 \\
3926.40
\end{array} \\
& 3326.40 \\
& 2765.40 \\
& 2675.40 \\
& 33086.40 \\
& \quad 2765.40
\end{aligned}
$$

EOCHESTIR

present Salaries New Bohedule Beginning

$\begin{array}{lr}\text { Chief } & 5400.00 \\ \text { Deputy ohief } & 4100.00 \\ \text { Battaijion ontex } & 3500.00 \\ \text { Captain } & 3100.00 \\ \text { Lieutenant } & 2825.00 \\ \text { Pireann } & 2600.00\end{array}$
$\begin{array}{cccc}5600.00 & & 5800.00 \\ 4250.00 & & 4400.00 \\ 3700.00 & 3800.00 \\ 3200.00 & 3300.00 \\ 39.00 .00 & \$ 3000.00\end{array}$ 
Table 5 continued

63

ROOKESTR (oontinued)

Schedule For Ine reaents on Appointiente And Fromotione After July 1, 1946

1at year zad Yoar 3 ad Year 4th Year 2th Yoar

Chlef $\quad 5400.00 \quad 5600.00 \$ 5800.00$

Deputy

Ohl of $4100.00 \quad 4250.00 \$ 4400.00$

Battalion

Onief $3500.00 \quad \$ 3700.00 \quad \$ 3800.00$

Oaptain $3100.00 \$ 3200.00 \$ 3300.00$

Lacuton-

ant $\quad 2800.00 \$ 2900.00 \quad 83000.00$

Firvenan $\$ 2200.00 \$ 2400.00 \$ 2500.00 \$ 2600.00 \$ 2700.00$

OHIO

CIHC IERATI

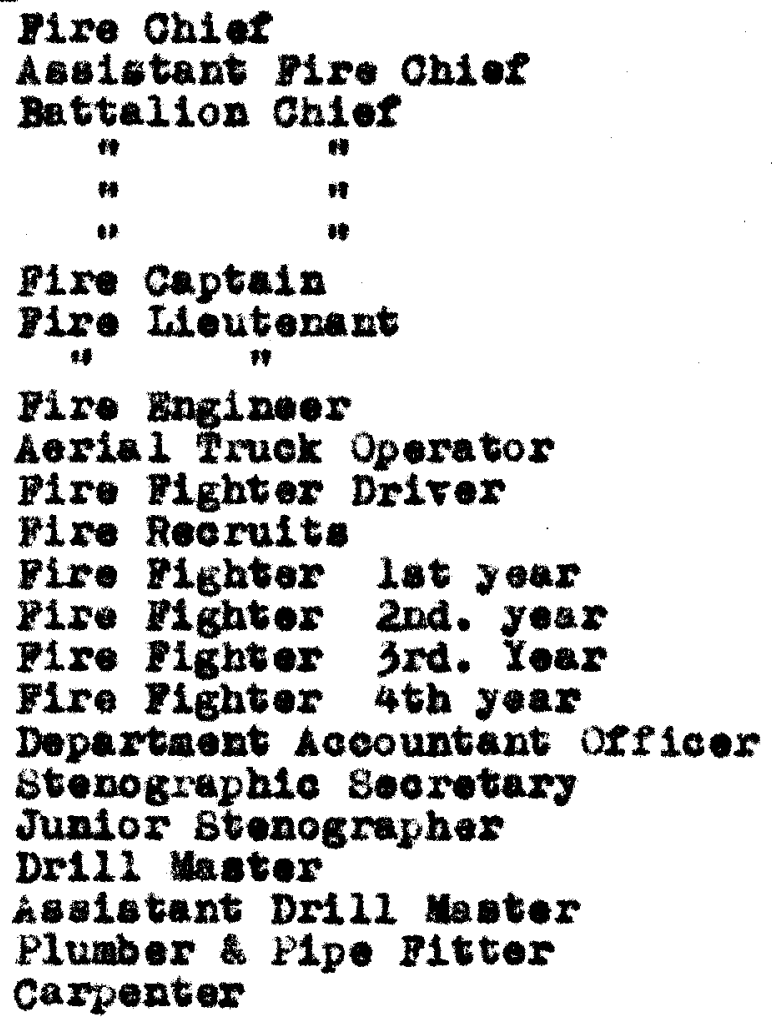

6518.88

4778.88

3518.88

$\$ 3998988$

3879.88

4028.88

$\$ 22910.24$

2654.40

2783.28

2589.36

2589.36

2523.60

1910.88

2050.56

32188.08

2323.92

2457.60

3338.88

2783.28

1769.28

4118.88

3157.92

3072.00

2952.00 
Table 5 (continued)

64

CIMO IMKaTI

(oontinued)

Truok Driver

Suporintendent of Pire prevention

A esiatant superintendent of Plre prevention

P1x Prevention aruon Inweatigator

Distriot supervisor of Pire Prevantion

Distriet Supervisor of Pire provention

Plre Pighter, 4th yoar. assigned to M1xo Prevention Bureau

Bonlor Btenographer Automotive squipment Painter

Hire Hose Repairman automotive Repalr Porean Automotive Repairman Buperintendent of Conmunication

Astistant Superintendent of Cormunication

pire Llaxn operator

Bre Alar Telephone Operctor

Cominication Foreman Comandoation Inetrument Maintenance Men

Communication Cable Splicer 2910.24 communioation Hineman 2783.28 Rudiotriolen
2219.44

4278.00

3157.92

2719.20

$\$ 3035.04$

2910.24

2457.60

2323.92

2654.40

2654.40

82783.28

2523.60

4838.88

3878.88

2783.28

\$ 2323.92

3218.64

2910.24

2783.28
2719.20

CoLULBUS

chlef

Assistant chi a

Butielion Ohiter Secrotary

Oeptain

Lieutenant

pire Pighter
Let yaer 2nd yoar 3rd yoar 4th year

3960.00

4140.00

34320.00

4.500 .00

31.20 .00

3240.00

3420.00

3600.00

2760.00

2820.00

$\$ 2880.00$

3000.00

2760.00

2820.00

2880.00

$\$ 3000.00$

2580.00

$\$ 2640.00$

2700.00

2280.00

2340.00

82400.00

82460.00

1920.00

$1980.00 \$ 2040.00$

2160.00 
Cutungus

(Cont1rued)

18t yoar 2nd year 3rd year 4th year

Superintendent

of ma Intalnano $3000.00 \$ 3180.00 \$ 3360.00 \quad 3540.00$

Ceneral shop

Foxeman

Superintendent -

Pire pollee

Comenul oetion

Line Boreman

Lineman, Grade"A"

Chief Rudio Techniclan

Red to Techniolen Motor Bquipan sechanie

Foreane, Fire

$2460.00 \$ 2520.00 \$ 2580.00 \$ 2640.00$

Hydrant Haintenanee Senlor Clexk sten-

ographex

Iire olerk

Fire Hydrant Repairaan

Malntalnance Mechan10
$3000.00 \quad 3180.00 \quad 3360.00$ $2460.00 \quad 2520.00 \quad 2580.00$ $1920.00 \quad 1980.00 \quad 2040.00$ $2460.00 \$ 2520.00 \$ 2580.00$ $1920.00 \quad 2980.00 \quad 2040.00$ $\$ 1782.00 \$ 1848.00 \$ 1914.00$ 1920.00 $\$ 1980.00 \$ 2040.00$ $1620.00 \quad 1680.00 \div 1740.00$ $1560.00 \quad 1620.00 \quad 1680.00$ 3540.00 2640.00 2160.00

$\$ 2640.00$ 2160.00 1980.00

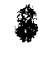$$
\cdot
$$

TOLEDO

\begin{tabular}{|c|c|}
\hline 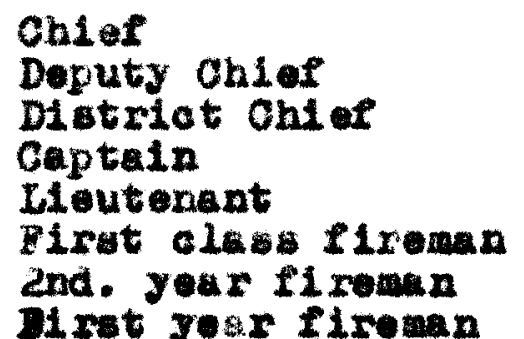 & $\begin{array}{l}5040.00 \\
4380.00 \\
3900.00 \\
3480.00 \\
3240100 \\
2940.00 \\
2750.00 \\
2520.00\end{array}$ \\
\hline
\end{tabular}

TEXAS

DALtas

SAN ANTOKIO

Base pay of privete 2496.00 Ho othor inforation given.

Base pay of private $\$ 2040.00$ Plus service pay of 5.00 for each five years of bervioe.

No other information given. 
VASHILEROR DATRLE

$$
\begin{array}{lr}
\text { Pay soale of fireman } & 2520.00 \\
& 2640.00 \\
& 2700.00 \\
& 2760.00
\end{array}
$$

T IGOASII

TLAAURES

No I1re Dopertnent answore received. 
Table 6

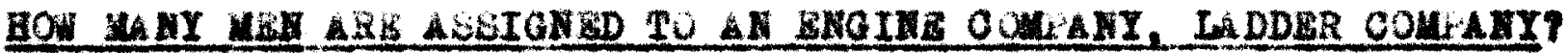

AIABA

BTRTregas

Sing ine Company: High Valua DLstet -5
Ladder Company:

GETTORLTA

OAxtand

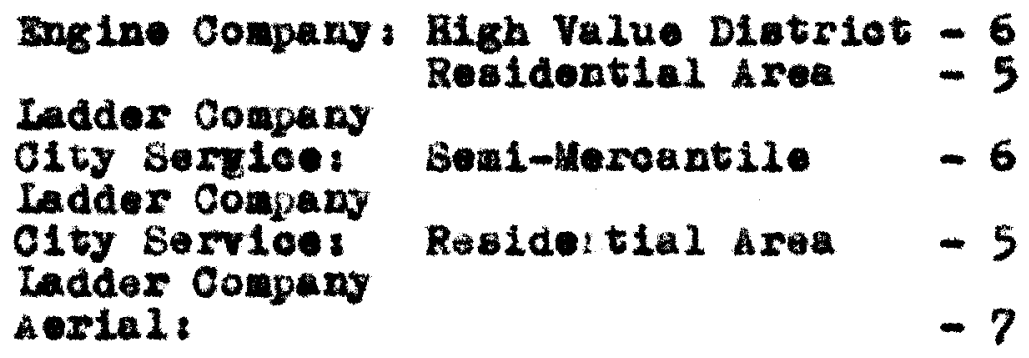

COLOIZADO

DEWV

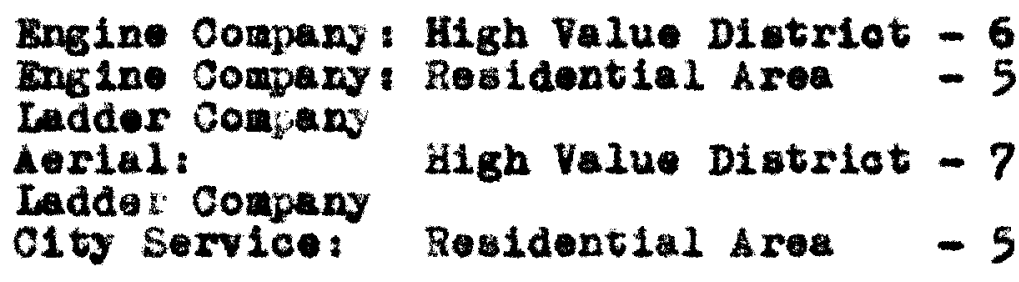

Singuora

DOUISVILLe

Engine Company: High Value District -12

(2 shifts)

Engine Compeny: Residential Area -10

(2 shifts)

Ledder Company

Aorial:

Bntire City

$-20$

Guad Company Bntire City

(2 shifts)

$-20$

(2 shifts)

LOUIBIGNA

VET ORLEKS

No Pire Department answers received.

MINABSOMA

BT. PAUL

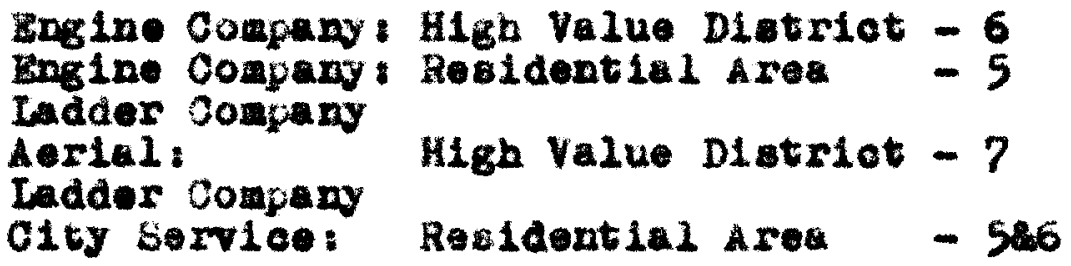


Table 6

68 (Continued)

YBDI YORK

BDCHESTER

OHIO

CIMC INRA T

COLOMBUS

TOLSDO

Tax

DALLAS

BAN ARTONIO

MashINGRON SHसTLE

TISCORST FLWAUKar
Wingine Company: Entire City -10 (2 ahifte) Ladder Compeny: Entire City -12 (2 shifts)

This question not anewered.

Bngine Company: entire City - 5 Ladder Company: Bntire city - 5 Bagine Coupany: Sntire City - 4 Iadder Company: Entire City -4

Angine Company: Rntire City - 5 Iadder Company, Bntire C1ty - 5

Bugine Company: intire City - 6 Ladder Compeny: tetire city -6

Engine Compan, High Value District - 7 Bngive Compeny: Residential area - 4 Ladder Company: High Value DIstriet - 8 Iader Company: Residential Aren - 5

No Nire Departent answers recelved. 


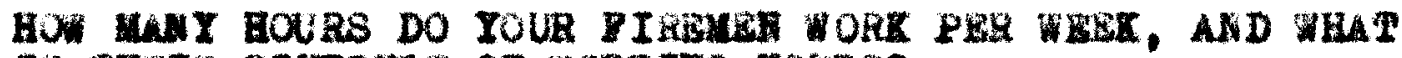
IS THEI SCHRDULS OR MOQR IMG HOURS?

ALABAHA

BITLTCMA

OACIPORNIA

WAKLAWD

COLORADO

DEIVVRE

KaYTOCKI

BOULST ITLE

SOUTSTANA

Dinto ORTLAKS

UINTESOTA

BT. PLUL

NBW YORK

RUCALSTTR

Naro

OTRTHWI

COLULPU.

TOLIDO

Fax

DALLAS

BAT AWTOKIO
72 bours. Alternate every 24 hours wh 48 houre off per morth. 14 daye vaction por yeax.

72 houra. 72 bours sohedule.

Q4 houxs per week. Alternate every 24 hours.

Q4 hours per week. Altermbe overy 24 houre.

Ho PLre Depertment andewer received.

72 hours. Altexnate evexy 24 hours. Dne day off overy two weks. A100 off on 11 recognized holldays.

70 houre. 5 day toure $(8$.... to 6 p.e.) then 48 hours off followed by 5 night toure ( 6 p.m. to 8 ....) followed by 24 houre of:.

This question not andered.

72 houre. Alternate every 24 hours.

56 hours. 24 hours on duty, al terniting with 48 hours of $x^{*}$ duty.

72 hours. Altarmetag every 24 hours. 2 days oft each 2 weekr.

72 houre. Alternating evary 24 hours. 
Table 7 (Oontinued)

PSHIEGTOA

SEATITHe

48 hours. 3 elght hour shifte for 6 coneecutive days with the seventh day off.

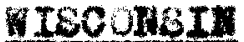

THLATKEE

Ro Ar Department anowers received. 
Table 8

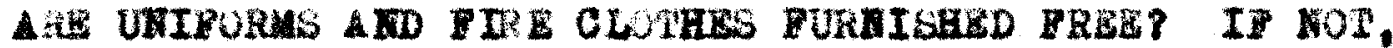

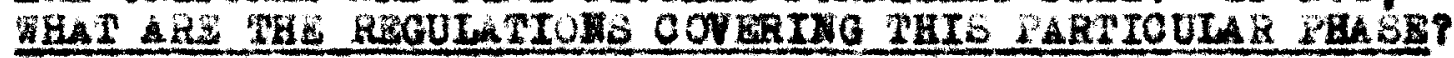

AIe Bing

BIRTINOWh

CALITONHIA OARTAKD

OULOKA DO

DBCY

KEWTUCRX

BOU1STTLE

LOUTSTANA NBI DRTokn NS

IINK BT. PAUL

NEV YORK

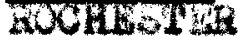

OHIO

OINC INATI

OLUMBUS
No. Onls elre helmets are furntabed exe.

No. Unifore spolflcatlons are at $u p$ by the Ohlex of the departnent. Heabors nust proaent new uniforas for inapection for cpec11leation conformity.

Men are fumb ahed with oloth for full unifora ter 1 gear service. but must pay for tayloring.

A11 dress uniforas are turnished by the aployese. Helmetis, Lire Iighting cotta, boots and nighthamks cre Iumished by the c1ty.

Do Fle Deyartaent answere recelved.

Uniforms, overcosts and ospo are furnished by tho employees. Helmets. salnecats, boots and nitiens are furnished by the elty.

\section{Annualiy inspected uniforns furniebod by the exployeea. Fire olothes are furnishod by the olty.}

Ho answer to thl question. Bo. 
Table 8

O410 (Cont1nued)

TOLIDO

Taxas

DALLA:

SAL AKronIO

WABHInGRON

SERThtes

IIbCoNSII

MITAR UX.
72

Piremen are given 25.00 per yoar for unifor upkeep.

Buremen are given 50.00 for clothes annually.

No.

Wo. Only helmets are furnished by the city.

Wo Hre Department anowers reoulved. 
Tablo 9

ARE WGMBRS OP YOUR DEHARUENT TRCABIZED IMTO A UNTOR,

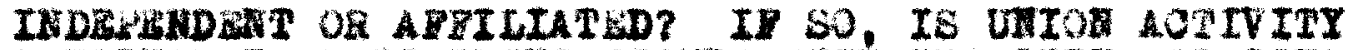

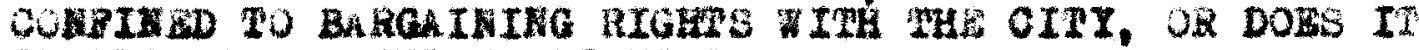
IXOLUDE THE RIGHE TO STEIRE?

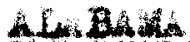

BTaxirank

CALIF RUIA

SKLLAD

CULURDO

DGivisa

BENIUCKX

LOUISVDLW

LOUTSIANA

ITW ORL WAKS

MIN⿴囗十⺝EOTA

ST. TRUL

12. YORK

TOCHEST2
Affiliated with the A. F. of L. Right to bargain but no right to strike.

Yos. No right to strike.

Afflllated with the A.R. of L. Right to bsrga in but no right to strike.

Afflliated with A. R. of I. Right to bargaln but no right to strike.

Wo Bire Dejartment mawere reoelved.

Afelliated with the A.P. of I. Alght to bergein but no right to atrike.

Piremen are organized lnto an independont associetion, known as the Peld Piremen's Ald Association. The AsBoe1ation's eotivity in additionto bergalning rights with the alty, inoludes a Pormonal Loar Assoclation for mombers and retirement and deach benefit fund. There is no right to strike. The Assoeiation is not affiliated with any labor eroup.

No answer to this question

Afrillated with tho A.P. of L. Right to berga1n, but no right to strike. 
Table 9 (Continued)

\section{4}

OHSO (Contirued)

TOLUSDO

Affiliated with the A.P. of L. Right to bargain, but no right to strike.

PEXAS

DA.ALS

No.

SAII ANTONTO

No.

NASHINOROS

BEATTLE

Afilliated with the A. R. of I. Right to bargain, but no right to otrike.

ISOONSIS

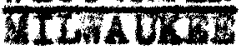

Ho Hire Department answers received. 
Table 10

HOW WAY PIRTi STAPIOKS AKE THARE?

\begin{tabular}{|c|c|}
\hline 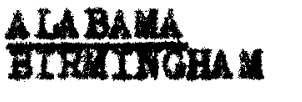 & 24 \\
\hline$\frac{\text { GALIPORnIA }}{\text { OARLARD }}$ & 25 \\
\hline Ouroando & 22 \\
\hline 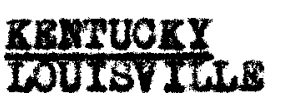 & 22 \\
\hline$\frac{\text { LOUTSIARA }}{\text { IRT OKLEANS }}$ & $\begin{array}{l}\text { Wo pire Dejartment answers } \\
\text { recelved. }\end{array}$ \\
\hline$\frac{\text { MrWNGSORA }}{\text { ST. BR UL }}$ & 19 \\
\hline 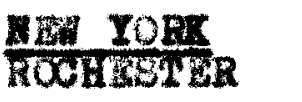 & 23 \\
\hline$\frac{\text { OAIO }}{\text { OIRE IMNA }}$ & 37 \\
\hline OOLUMBUS & 19 \\
\hline ROLEDO & 21 \\
\hline$\frac{\operatorname{TSXAS}}{\mathrm{DALLS}}$ & 26 \\
\hline SAN ANTORIO & 23 \\
\hline 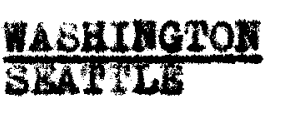 & 35 \\
\hline$\frac{\text { recoss In }}{\text { irthrate }}$ & $\begin{array}{l}\text { No fire department answers } \\
\text { recelved. }\end{array}$ \\
\hline
\end{tabular}


WHAT IS PHEIR LOCAPTOK HLAM?

ALARA GIRTOUOHAM

CALITURTL ondento

COLONADO Defrve

G HATUKX WoUTSVTLL

LOUTSIANA Dew ORLALA

IINNLGORA BI. FAUL

Nay YOBS TUCHAST
Equal distributionin accordance to density of population, consercial and industriel districts.

Strategically placed to provide a maximun in efelolency to the ocmmatty it oerver.

No definite looution plan

Realdential areas are served by quad Companies and Pumper Companies, strategically located. Thres Aerial Truok Companies (one in each district) serve the high value districts, oungested areas, all bulldings ovar three storles in height. Two Aerial Trucks and threo Sagine companies respond on the first Alara in business, botel, and hospltal districts. Seventeen Puaper Compantes are located according to hazards involved.

Do Pire Department arawerc recelved.

Statlons have been rolooated for motor apparatus and apyroved by the National Boend of pire underwritere.

Thare is no polnt within tho city linits which any not be reached by the plite Departaent ithin $y$ anutos after an ara ba sounded. 
Table 21 (Contimued)

OHIO

CIOINAAT

cotortsus

TOLODO

TERA

DIness

SAL ANTOMIO

ASEISGTOA

STALTE

ISCONSIA

MILWA KLF
No answer to this question

Ho anewex to thlo question

The Ilre atations are located under the old systen used when the horse-dram appartutus were maintalned. Conoideration 1s under way to relocate unaer motor aparatus standards.

Located as newrly us posible, adconding to value and rea.

Located accoraing to populated distriote.

Looatlon ls based upon topoeraphy. values, life hazard, and an enelnoered and integrated plan of over-ali fire defense.

Wo Piro Department answore recelved. 


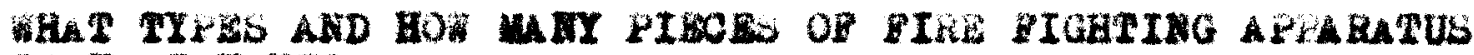
DO IOUR RAVE?

ALBSH BTIIIOMA

CA CIROQUTA TALAD

COTORADO Digrver

RorvokX EOUIBVILLE
42. Principal1y Seagrave and Anerican1.. Brave Also tour tacks. Funer oapas1t1ee: 600,750 , and $1000 \mathrm{gal}$ lons por unute. Ladder trucks: 65,85 end 100 feet.

Ohonical Coxpan (Rescue Utility), Triple Combinetion Punpere. Triple Combination Pumpers with Hose Wagon, Truoks, City Service, Trucks, Aeriel Hill Fire apparatus. Hght Wagon, Supply Magon, Reserve: Trucks \&ingen, Shop! Miselinneous

1 Quad Combination, 14 Triple Comb1nation Punpers,

3 Double Combination Puapers, 3 Hose Theno

4 Aertal Truoke, 7 clty Service Ladder Truake,

2 Aquad Fagons, 1 Apparatus under conetruction

6 Reserve Punpers, 8 roserve Hose wagons, I reserve Cliy Berv1ce Ladder Truck, 2 reserve Traotors for Aorlal prucks, I resarve Chemlcal Pruck.

4 Aerial Trucke, 1 Hook \& Indder 01ty service Pruck.

5 Qued Comblatione, 30 Pumpers, 1 Chenloal Truok

1 Water Tower, 4 service Trucks, 1 Communication Tower Pruok, 2 Alam Conmunioations rruok, 12 ofricers cars. 
LOUISIARA

BHA ORTMAS

LIIN DSOA

TIMEAYOTIS:

BR. FAUT

WoHeseri

OHXO

OLIOINA II

OUUHRUS

POLABO

BRAS

Detitus

SA* ANTOLIO
Wo Pire Department anewere reobived.

No repllas reotred.

1 Resoue Squad Truck, \& Double Oomblnation Punpers, 9 Tripplo Comblnation Fumpers, 1 water Towex, 3 Aerlal Trucks, 2 olty Service and Chouleal Truoke. 2 c1ty servioe Booster rrucks, 1 guad Combination Aerial rruok, 2 Hose wagon, 1 Balvage Truek, 5 serviee Trucke, 7 Oftloers cars. 3 Tripple comblnation Reserve Pumpers, 2 Double Conbinstion Reserve Puppers, 2 Resenve Aexlal Trucks.

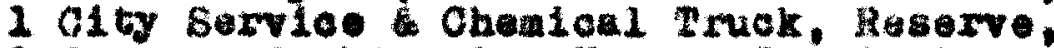
1 Reserve Gombinetion Hose E Chenioal Truck, 1 Reberve offleer car.

Fumpers, Aerial Trucks, bervice Trucks, watar Towex, High Prossure Fog zunpar. and Ealvage Wagon. 33 pleces in 11 re fighting ervice, 9 in roserve. Fumper capacities run fron 500 to 1500 gallone par mute.

62 in active service. 7 in reserve. In addition thexe re two abulances, 19 autonoblies, 5 trucke, 1 Tank Truek.

52. Al1 Seagraves.

18 Pumper, 3 Hose Compant s, 8 Laddex Comyantes. 2 Squads.

33 Puppers, 11 Trucks, 1 Tater Tower

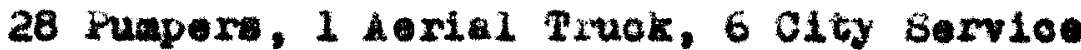
Trueke 
Table 12 (Cont1rued)

80

WASH IFOTOD

Skatritis

Types of apperatus include punpers, dity Servioe Trueks, Aerial Pruaks, Weter Tower, and Plre Bosta.

T $1800 \mathrm{OS} \mathrm{m}$

TILARUKRE

Mo Plre Department answers received. 
Table 13

81

GIVE RHE AVGRAOE $\triangle G E$ OF THE AFEARATUS?

A EAaAa

BInturany

Q yare.

QATIPORUTA

OALTMD

11 rearis.

OOLORADO

Dervat

20 raars.

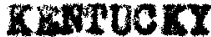

100L8VIITE

9 yaare.

LOUISIAM

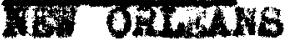

to Dire Departnent anowere received.

UINEBSOIA

SH. PAUL

27 gars.

Nom YORK

ROCHLS12R

15 yeare.

OLIO

OTWINKL TI

lio answer to this question

CoLduBnS

5 yeare.

POLDOO

10 years.

Paxs

DIWLS

15 yeaxe

SAL ANROAXO

8 yeaxe

MALIECOOL

SBIML

10 rears

TSOONSIH

DIUAVUTE

No Plro Departuent unswer recelved. 


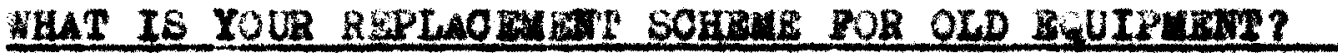

ACBNHE

BIflowgh

OALITORULA

OARTaW

COLOEADO

Drestrat

REIUEXX

DovISYITtwa

DOUTSLAM

Mro onlenters

MTNWONA

ST. RKUL

Wis roax

Rochisstide

OHTO

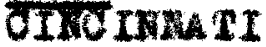

CUTUIDUS

POLODO
Trying to replace two pleoes a year.

To mintalg equipmont at a high atan. dard of efflolenoy. To replace oldex -quipaont on a graduated progreseive pina.

No definite sobere for replacenent of apparatus.

8won new pleose of apparatus bave been purchased within the past year. In cidition two nore runpere are now on order and 112 be placed into servise soon. Several nev appaxatue laoluding an A erlal truok wll be purohased this year. This plan 111 be followed until all ant lquated equipaent has been replaoed with now and nodern apparatus. bndar this plan no plece of equipment w11 have been bought more than 15 years a.co.

Io In Departuent answers reoelved.

to plan.

Complete nodernisation prosra is now in progreas.

Regulax replacoment plen for wornout equipnent is belng followed.

When finanoes 111 perait

Pive new epparatue por year, over a Live yaar plan. 
Table 24 ( continued) 83

DOAS

DALILAS

SAK ANTO IIO

WASHIROROA

Bghrots

WISOONS TI

TILADK KB:
To replace old equipment when appropriatlons and apperatus avellable. $12 \mathrm{new}$ pumpere are now on order.

Replacine two to three apperatuo each year.

Replacement operates on a Rive-year basia that is rovived annue $11 \mathrm{y}$.

No Fire Departwent answers recelved. 
Table 15

84

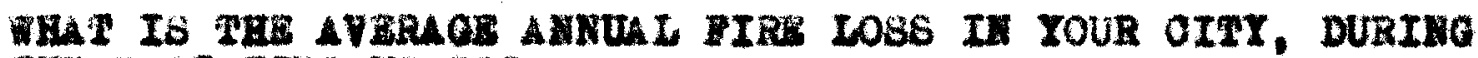
PES PAST PIVE YEKR6?

A IA BAS

Stanirema

CA ITORAL

oxtaAD

Q0T0RADO

DEXTES:

EnNuCrY

Wo0ts inter

LovTEILAa

T2x ortumas

UnTRA Pots

62. PhUL

NE XORK

RockCBStan

orro

OHOWHAT

Corminus

TOLEDO

Taras

DELTAS

S4N ANTOKIO

IscousI

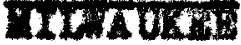

- 581.875.95 Pox capitas 2.077

$\$ 1,244,223.16$ Per cap1t. 3.8286

-640.452.22 Per oup1ta: 1.8298

8436.756 .29 per oapita 0.9194

Do 15 Departinent anemere reoetved.

653.028 .00 Pex capita $\$ 2.1767$

578.131 .00 Per cap1 1.6518

* 890.357.00 Por cep1ta 1.8954

1.5240 per ap 1 te

\$50,000.00 res eapita: 1.9260

1.342 .231 .00 Par oap1ta, 4.1944

300.408.00 Por capita: 1.2658

Ho Fise Departint anerrers recelved. 
Tab10 16

DESORTBE YOUR MTRE ATARE SYBTEY.

ALABA BA Braruretar

QATRORIIA OAKLAND

OOTORADO

Detrithe

BSWTUCX COULSVINA:

IO0ISTANA HE⿰亻 ORWRTS

$1211250 \mathrm{~A}$ 52. PAUL

NBS TORX ROOHCSIMR

ORIO OTKOIMATI COLULBUS TOLaDo
Camowell syctem. Inttalled in 1921, kept falrly well up to date ith replacements. Redio servioe added auring 1946. Two-way Eow 10 1nstalled on practical1y a 11 coulpoent.

Camewell systen under superviston of the Electrle Departaent, olty of Okland.

The Pise Alare systen is now belng remodeled and new syeten is inthe maktng.

Cumell and Btar type. The flro alad transntter is the nost bodern in the United states. There is also anothar transaltter, R.B.X. Doand, box and relay boarda, alara reley boards, bettexy charglng boards, and 60 elreuit proteatos board. Ourrent 18 furniehod by the pixe Departnent's ow alectrio power to toge plant, whiob alco operates the tolephone allont aleme systen.

No Hre Dopartuent anmexe received.

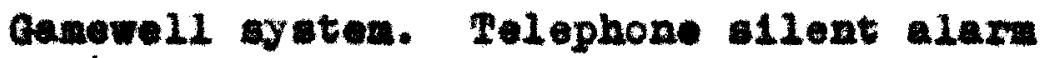
syctom.

canewell aysten. A completely nov reoelving and eending systom and station was installed in 1938.

Teletspe ayetem. Gamewe11 syston, two-way radio and telephone syoten.

camowel1 ayston.

Canowe11 ayaten, two-wey radio aystom. 
Tras

ixnors

Ganowell syoten, two-way radio syeten on all apparatus.

Bax AMTOWIO Camewell syatom.

WASIRGNOE

SEATtLS

4 contral offloe systom with alarme transmitted via coded signale. Also by rolce transmision, supplemented by the B1re Department two-way r. M. radio etation.

Iscons. I.

Irentoxis

Ho Fire Dopartment answers recelved. 


\author{
spotrox III \\ SURTEI IDDEX AND SRATISTIOAL TABLAS \\ PART II \\ POLICE DEARTAKTES
}


Table 1

HO MAT DISTRTCHS ARE THMRE?

SIABN14

Bhatirenan

15

CALITOEIIIA

OAkLAD

3

cororano

Ditiven

5

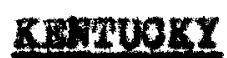

Wouls r The

4

Lourstana

Brit orwatis

7

Irviessora

BI. KAUL

24

ABSI YORE

Foutassirer

7

onso

OTROIMRATI

7

co Lumbus

102 night Dietriots, no epec1eio day distriets.

TOLSDO

15

Mares

DALTeS

14

SAN AMTORIO

$015 y-1 d 0$

isAIBGTOR

Bसmins

3

ISCON8II

ritun OKa

No Polloe Departinent answera reeelved. 


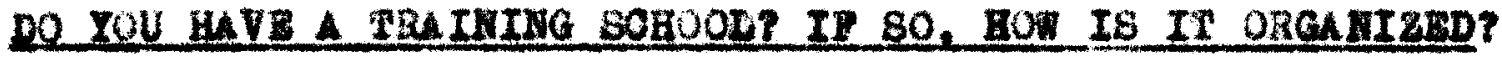

ACMBÁA

ETRIrTaA The tralning sohool is conduoted by eargeant wo is the inetruetor of personnel. The sahool runs for about twenty weeks, three nights a week, tro hours alght. All now offloers nuat atiend.

OALTHOLIA OLLTLED

The tralning cohool is under the supervision of a captain of Pol10e, with voluntary inetruotors from the devartant. It conelets of a $4-344$ ir hecruit rraining Couree covering all cubjecte. There is lso in-serviee training.

COLORADO Detivint

The tralnins sobool is conducted for all new men, and consists of lourty hours in the clese root, plus out-door traluing on flac-ame, nob and slot control. The basie prinolples of police work. eity ordinaness, and orimina Law are treased.

Tho Polloo Edueational Buroa is in ohsrge of the truining school where all now offloers are assigned, bafore entering aotive duty. The complete course reguires six weeks or claso room und fleld study. The progras is prepered by the Buperintendent of the Bducational Bureau and approved by The Chief of Polloe. Lbout $50 \%$ of the Instruotions are given by nobors of Polle Ealucational Bureau, who a re selected to instmot the school. These are ploked men tho have experlence and knowledE of the subject they are to instruet. If the reorult faile to make a pasing general average of 70 or better, he 18 autonationlly dropped a an omployec of the depertment. In-service tre ining rotates among groupe of 15 wen each for perlod of one week for ach group. 
ToUTSTHF sine oumans

THKGSOA 3i. FaUL

U) YORK Rooncosida

a 20

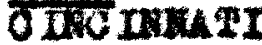

QLTES

motroD
The Pol1e Trainlng Divielon $1 \mathrm{~s}$ brench of tho Duroau of Operations and Iralning. operatin under the supervision of the Superintendent of Folles and in obarge of a cupervibor wo 18 a stafe offlecr. Soven full-tine 1netructors, one eupply offloex, one seoretaxy and two oustodlal workere congtitute the personnel of the tralning alvielon. There are ten partt Lne inotructors wo axe poelal1ete and nembers of the depertinent. Cuest ingtructore representing vaxious elelds of astivity related to law onforoenent axe called upon regulaxly for 200 tures. The reorult treining procransis alvided into three fofor alvislonst Menta 1. 175 houra. Lanual, 100 houre. Physionli 75 houre. There are listy sohool days of seven pertode eneh.

Now reomulte ano givan 30 duy of talaing covering all phases of pollee woxt. Ioonl judges, the shexlff, Coronex, to., and the ranking officers of the Pollos Departaent act as instructors. Dooasional in-tralning courses of instruction are given to regular. offleers by the P. B. I. and othar agencles. No set sohodule or progran.

Hew appointeea are given an extended course In polloe proceedure by Lioutonant of Trafning.

Iarge and nodom tra ining sobool and detalled program. (Vo turther informator given.)

Praining for 30 days for new results, when required.

Training sobool superwided by an 1nopootor and lieutenant. 90 days of trainling for new offleers. In-serviee tralnibg about

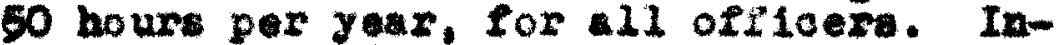
- luates use of 1 re arms. Law, court procedure, pol161.s, mileo and regulations. 
Taxas

Dxoms

SA ANTOMTO

ASTRCAOR SWIIITN

TSCONSIA

MTSAUR

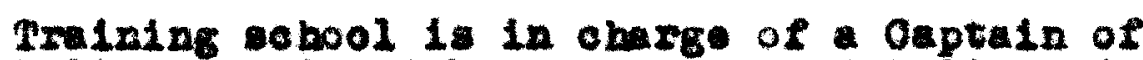
Pollee, cusisted by a Sergeant of Polloe. The rooult is enrolled in the pol1ee somool tor 6 weeks. Met thend elght one-hour claseos eix days a wesk. Bull instruetion given on all polise aubjots.

Training ebool undes aperviclon of the state Board of Rducation. Reeruits mist atcend $f$ of three wonthe. In-service ralning one bour ecoh week for 50 weeke each year for a.1 nembere of the departient. AlI polioe subjoots are taught.

Tralning achool adalnietered by a pireotor of Pollee Tralning. Sohool is a branah of the Technicel serviees Division of the Pollos Departient. The Sobool is inooontinuoue operetion and conducts three types of train1ig, besio; 12 weeks for eash recrult. Inexvice: 2 veek anmally for each nember of the department as well a speciallaed tralnIng.

No Polle Departuent answers reoelved. 


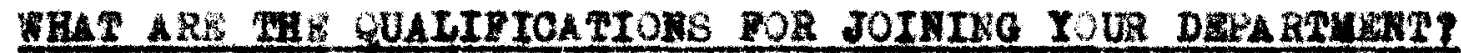

ALAMU

Btromtroun

CALTPORELA OARLAID

OOLORADO Drsivar

XavpuckY

Doorstowe

LOUISIAII

ABI denans

ITHESOA

ST. PAUL

HST YORK

ROOLRSTER

OXIO

CINO InEarI

COLUMBU8

TOLWDO
Civil serviee qualifications. Competitive -xadinations for 11 wo heet oertaln physleal and montal requiremante.

United states altizen of good character. Resident of the city of Dakland for at least 5 years. Age: 25 to 35 . Civil Service qualifleations.

Civil service qualiriations. Heightis'g" to $6^{\prime} 4^{\prime \prime}$. Welght: 148 to 235 pounds, wetht eocording to helght. Agei 25 to 35 . Must be in perfect physioal health.

Complota OIVil Servioe gualif ieation. Competitive axaminetions. High school chucation. Ase: 21 to 35. Minimum holght 5'9". Mnimua we1gt 150 pounds. Good noral oharacter and no record of prevlous arrest.

Olty Civil Service qualifications.

Age, 21 to 35. Minlmun holght $5^{\prime} 8^{\prime \prime}$. veight coording to height. Wust pas phreical examination.

Age: 21 to 30. Hnimum holght: "5'g". Hust pase sontal and physloal tosts and have on year of Junior Hith Sohool.

This guestion not answered

Physical and aental oxaminetlone. Age: 23 to 29. Hinimun hoight $5^{\prime} 9^{\prime \prime}$. We1ght according to holght.

Age: 22 to 32. Corresponding weight. Good hesith. Resident of Toledo for ten conseoutive years or a realdent of onlo with Jorld War Il exparience. Required to pass Civil servioe, physioal and written exanination. 


\section{3}

Tabie 3 (cont inuod)

TACAS

Dandas

Civ11 service qualif loations. Age, 22 to 30 . Mininua holght 5'10", minimun welght 160 pounds.

High Sohool education.

DAl AETONIO

Civil service qualifications. One year residenoe, elty of San Antonio. Guilified roter. Good moxhl character. Hust pass mental and physleal exaninations. Age 21 to 30 . Minimum beight 5*10".

Rashtworo: BSALTLE:

Residence city of Benttle. High Sohool education, full exaninations. Minimum

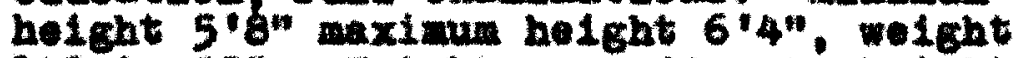
140 to 235 . Delght aceording to helght. Age: 21 to 30 . Rigid Civil Service qualificutions.

TS00XsI irThURde

Ho Pollce Dopartaont nawere recelved. 
Table 4

94

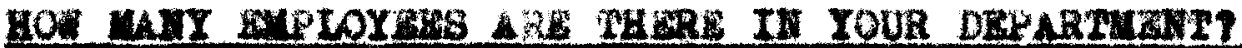

$\triangle D B G$ IIS

BIRIIIORA

316

CALrTORES

OARTALD

610

gOTORADO

DERTER

485

ranpucXY

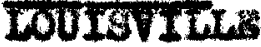

484

LOOTEIAN

But otwaras

900

4 IIIIS500\%

ST. RAUL

326

Hase

TOCEESTMR

458

onIo

OricinkarI

793

columbos

400

TOLDO

419

Texus

Dntats

489

SAN AnTOIIO

297

washrICEOL

Bratuth

649

ISONASIN

rITRUABs:

Ho Pollee Dopartment anewers rocelved. 
Table 5

WHAT IS THS SALARY SCALE?

ALBAS

BTAG INOHA

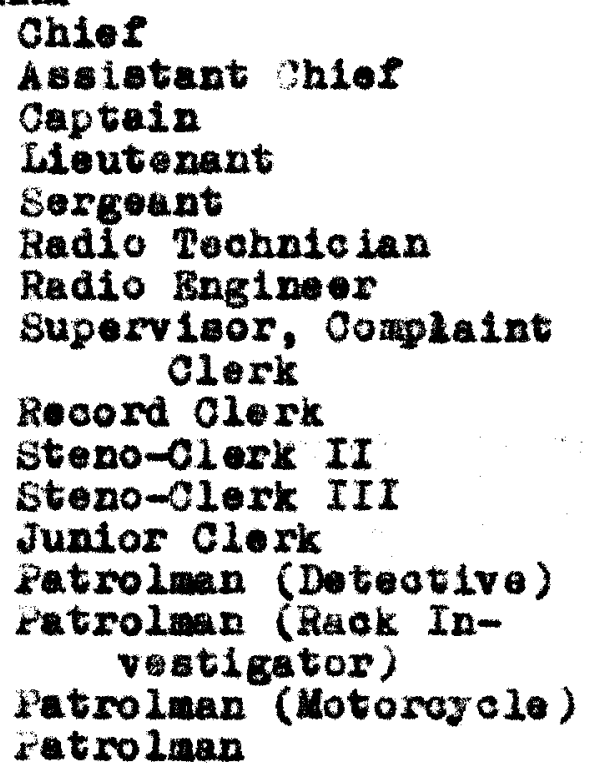

$\$ 4740.00$ to 5659.92

4260.00 to 4860.00

3240.00 to 3300.00

3060.00 to 3240.00

\$2880.00 to 3000.00

2760.00 to 3060.00

$\$ 3180.00$ to 3780.00

1940.00 to 2220.00

3060.00 to 3420.00

1980.00 to 2400.00

1680.00 to 1980.00

1620.00 to 1980.00

$\$ 2520.00$ to 2880.00

2460.00 to 2700.00

\& 2520.00 to $\$ 2760.00$

2400.00 to 2640.00

CALIROREIA

ORELAND

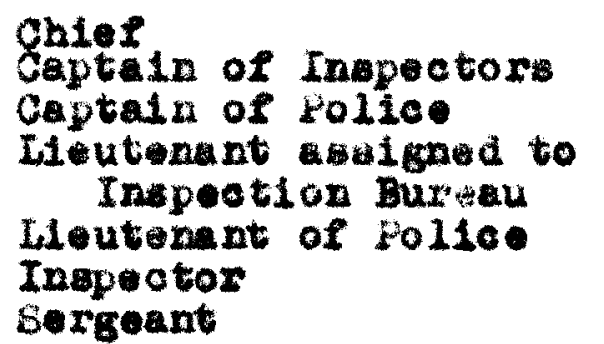

7980.00
6384.00
5592.00
4404.00
4104.00
3780.00
3636.00

Patrolanan

itatron

$\frac{\text { let Jeer }}{3000.00} \frac{\text { 2nd yoer }}{3156.00} \frac{3 \text { rd year }}{3312.00}$

COLORADO

DNWER

onier

Deputy Chier

Captain

$\$ 4630.00$

Sergeant

3516.00

\$ 3172.00

Surgeon

* 2550.00

2550.00
0 
Table 5 (Continued) 96

COLORADO

DBFV (Continued)

$\begin{array}{ll}\text { Custodian } & 2550.00 \\ \text { Detective } & 2481.00 \\ \text { Operator } & 2274.00 \\ \text { Hatron } & 2136.00 \\ \text { Pirst Grade Patrolman } & 2274.00 \\ \text { Socond Grade patrolman } & 2205.00 \\ \text { Third Grade Patrolman } & 2136.00 \\ \text { Pourth Grade patrolman } & 2067.00 \\ \text { Provisiond Patrolman } & 2067.00\end{array}$

TSKrUCKY Doterifue

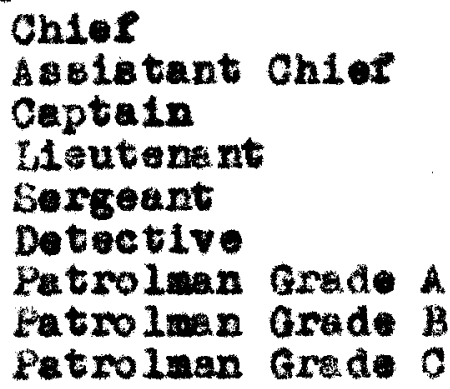

5000.00
4020.00
3180.00
2610.00
2340.00
2190.00
2100.00
1980.00
1860.00

LoUTSLAN IA ONLEA NS

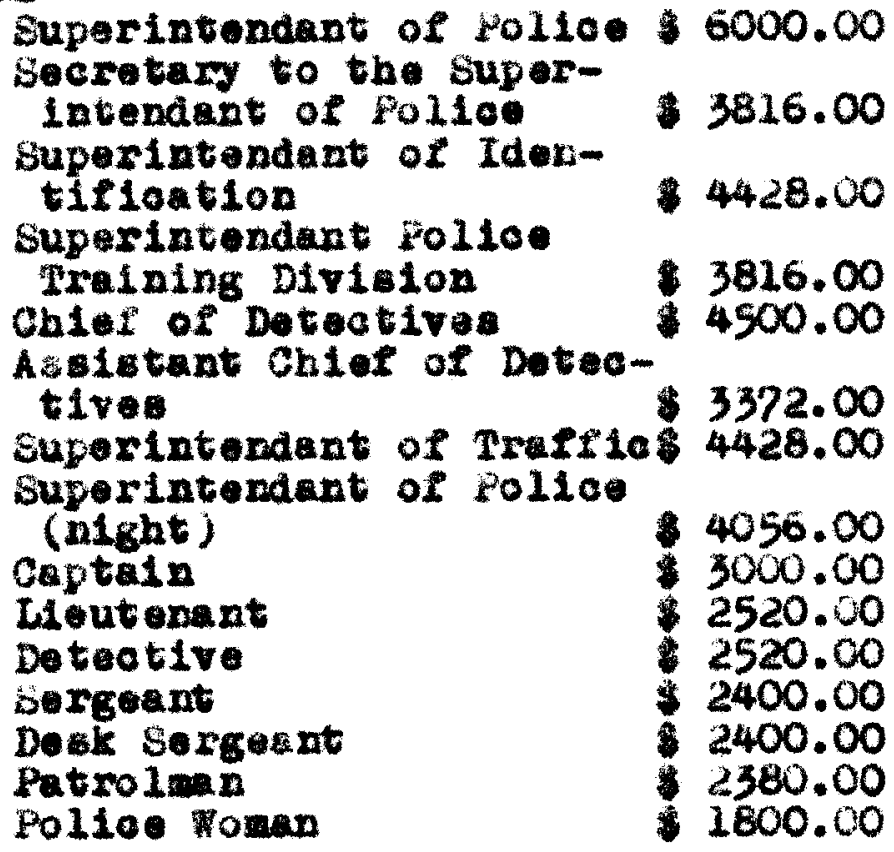


Table 5 (continued) 97

ATRR $\mathrm{TUNA}$

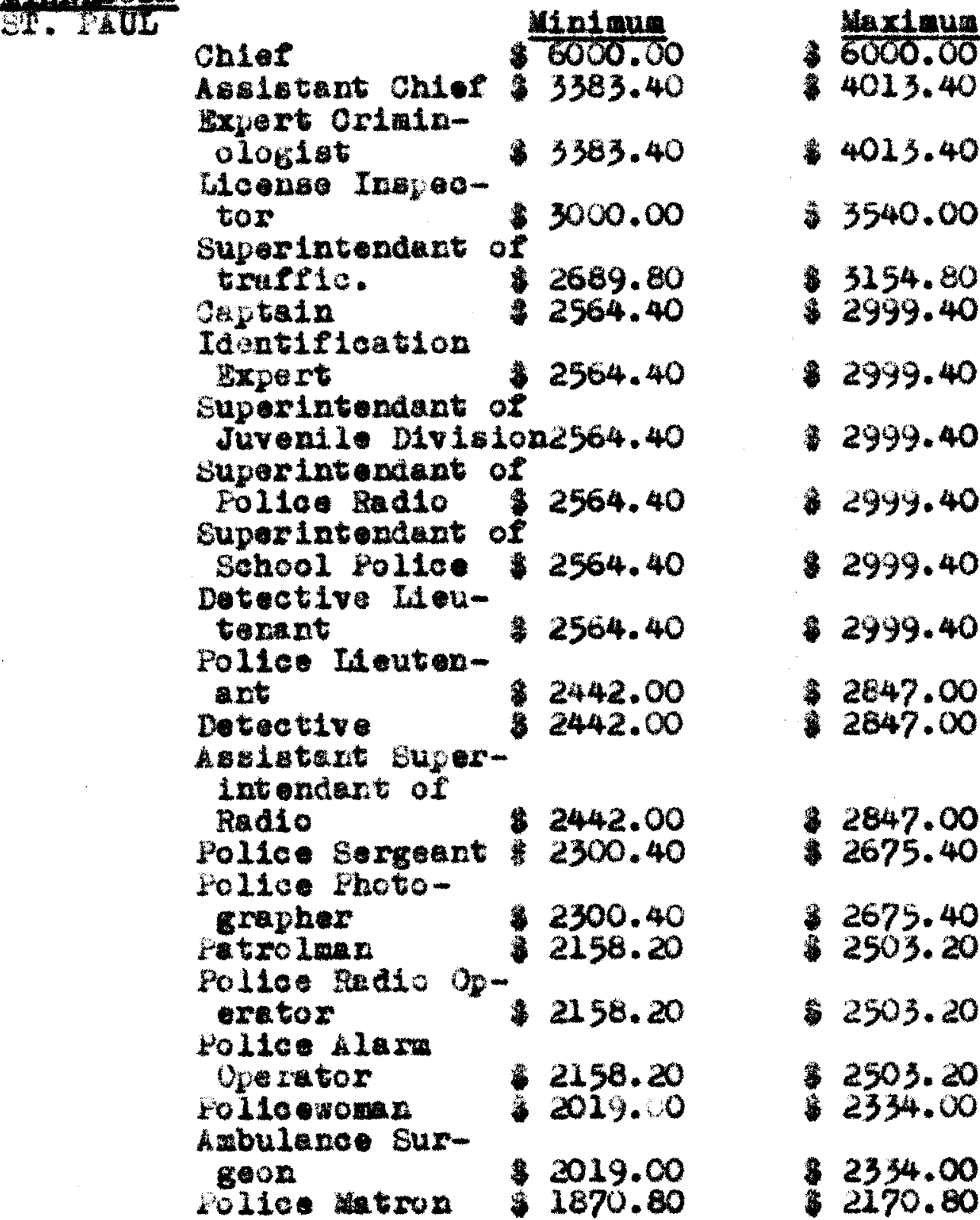

NEV YORK

aOChtorgh

Ohiof
Doputy chior
Inspeotor
daptain
Lout sent
Sergoant

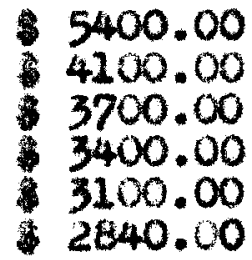


Table 5 (continued) 98

HEN YURK

ROCHSTris (continued)

Chier of Deteotives

Asoistant chier of

Desectiven

Patro Iman (Eupgrvibor Detectives

Patro Iman (Sugervibor

hocident Bureau

Patrolman

retrolman lat year

polle ewo an

4100.00

3500.00

3200.00

3100.00

2600.00

2200.00

2600.00

OAIO

TIW INAAI

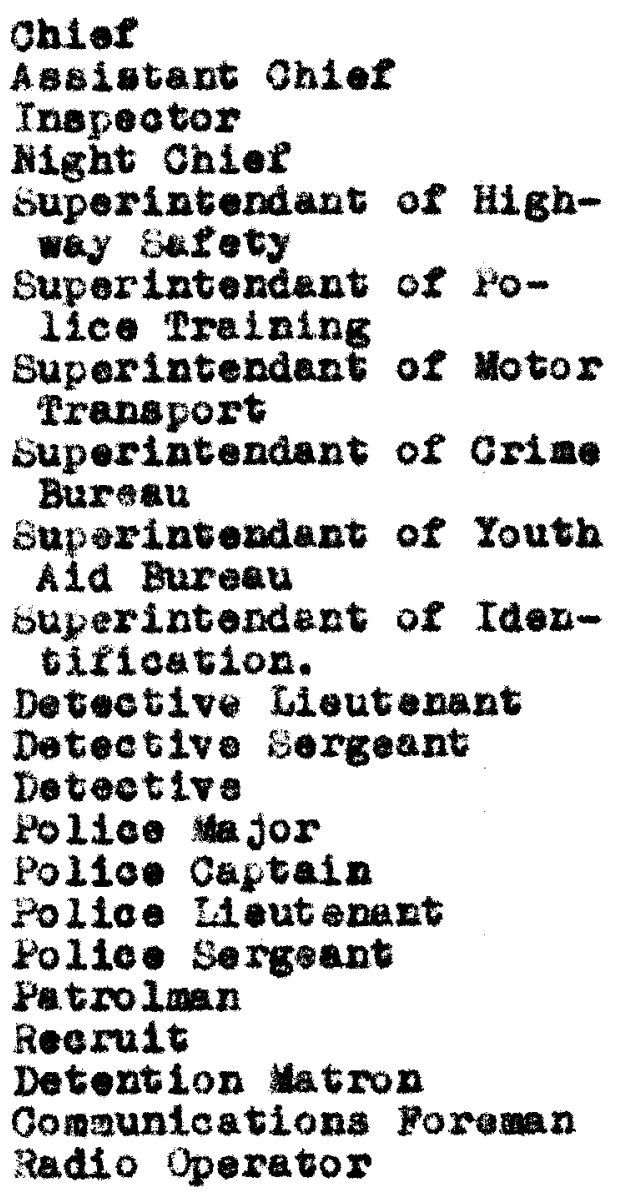

8528.86

4778.88

4278.84

4278.84

$\$ 4278.84$

4118.88

3878.88

4478.88

3518.88

3278.88

3157.92

3035.04

$2589.36-2719.20$

3878.88

$3518.88-3878.88$

3035.04

$2783.28-\$ 2910.24$
.52050 .56

$2050.56-\$ 2457.60$

1910.68

1553.28

3218.64

$2719.20-2910.24$ 
Table S(continued) 99

0110

CIRCI HathI (contirued)

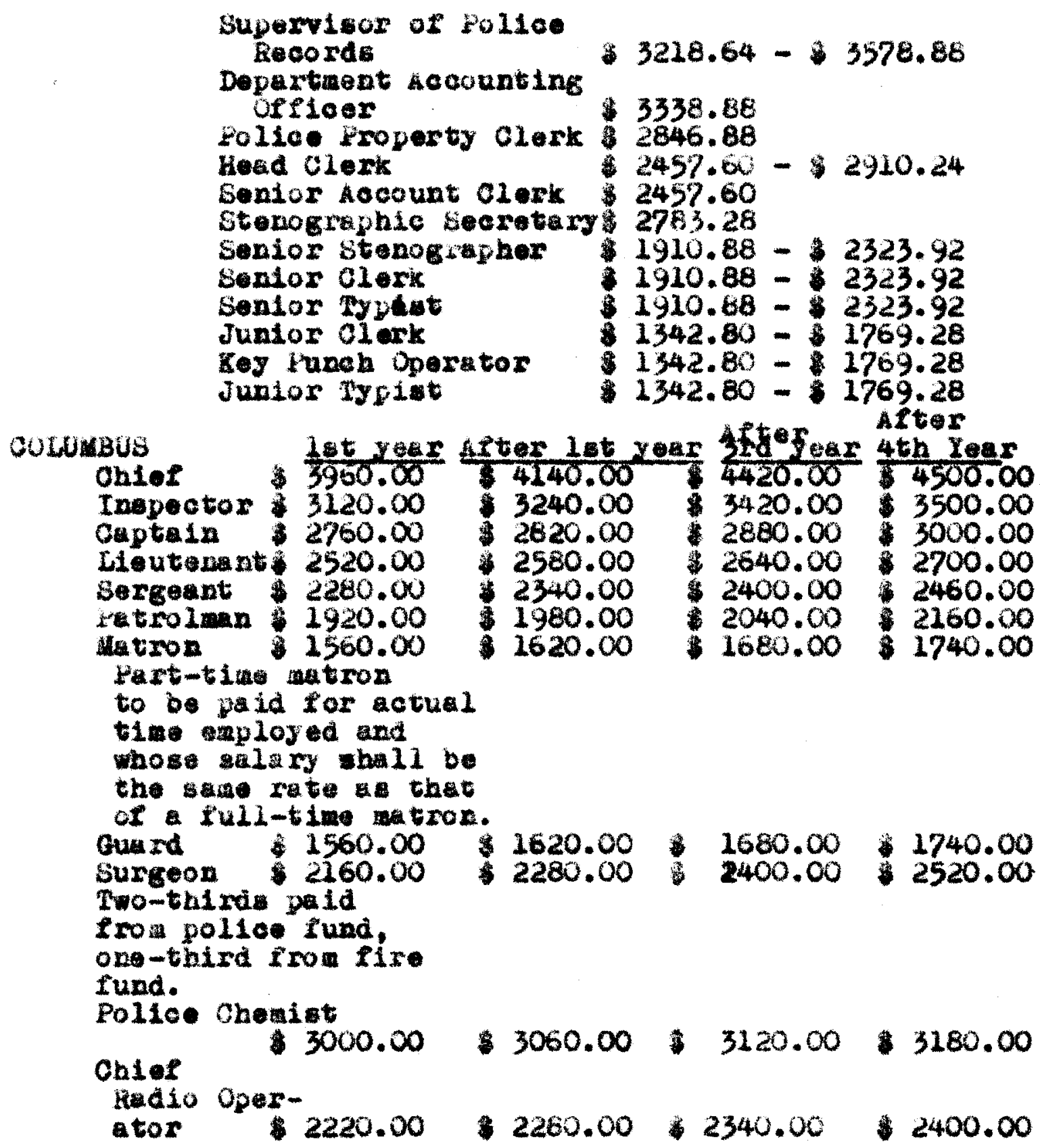


Table 5 (continued) 100

COLO

After After After

lgt yoar iat year $3 \mathrm{rd}$ yess $4 \mathrm{tb}$ year

Rad10 operutor $1920.001980 .00 \quad 2040.00 \quad 2160.00$ Yollce voman \$1680.00\$1600.00\$1860.00\$1920.00 Ma intenance

Hechanto

socretary $2760.00 \quad 2820.00 \$ 2880.00 \quad 3000.00$

$1740.00 \$ 1800.001860 .00 \quad 1920.00$

Principal clexk $1,80.00 \$ 2100.00 \$ 2220.00 \$ 2340.00$ Polloe Reoord

Clerk

Olerk sterogra -

pher

$1620.00 * 1680.00$

$\$ 1740.00 \$ 1800.00$

Telophone

TOTSDO

Chier

Inapector

Super Intendart, Burea

of Identifiestion and record.

As sistant Buperinterdant super Int endant Labortory

Secretany

Captain

Lieuterant

Lieutenant Dispatcher

Ifleutent Identification

Lieutenant Detective

Sergeant Detective

be rgeanc

Sergeant Disptohor

Bergeant Jaentification

Bergeant A cident squad

Corporal Dispetcher

patrolman Acoldent Squad

Patrolman Criane Prevention

Patrolman Motoroycle

Patrolenn

rolloe Woman

Follco Toman probationary

ratrolman probationaxy

Polyeraph operator

5040.00
4380.00

4380.00

$\$ 3900.00$

3900.00

3900.00

3900.00

3480.00

3480.00

3480.00

3480.00

3240.00

3240.00

3240.00

3240.00

3340.00

3060.00

$\$ 3060.00$

$\$ 3060.00$

3060.00

2940.00

2940.00

2520.00

2520.00

3480.00 


\section{TULDO (continued)}

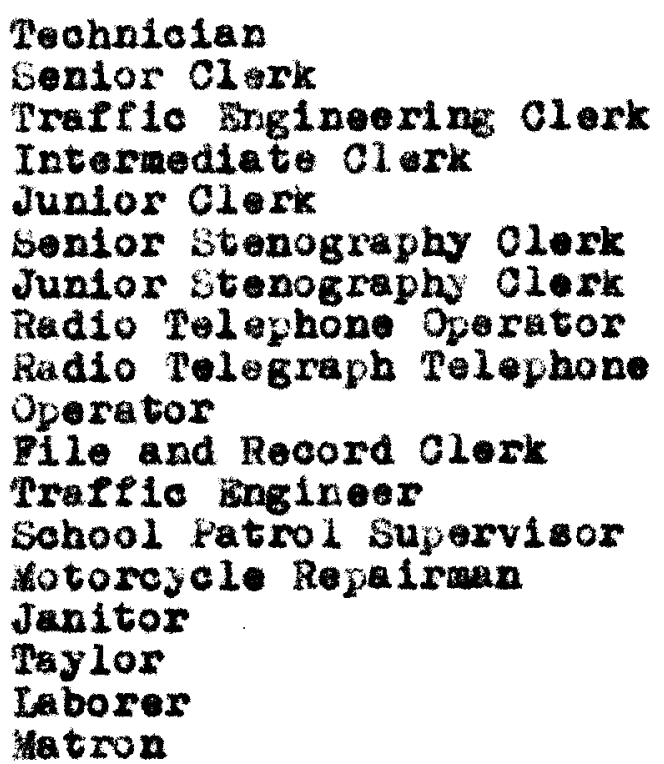

PQXAs

DALTAS

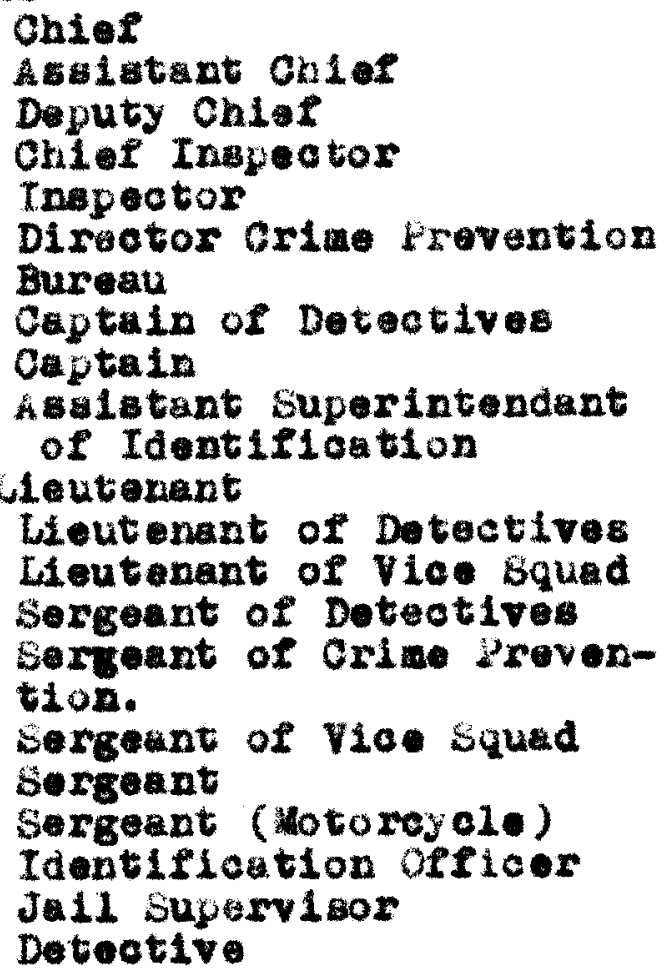

6499.92
5100.00
5100.00
4380.00
4332.00

4332.00

4320.00 4104.00

3156.00

3144.00

3144.00

3144.00

2988.00

2968.00
2988.00
2856.00
2976.00
2988.00
2904.00
2856.00 
DALIAS (continued)

\begin{tabular}{|c|c|}
\hline 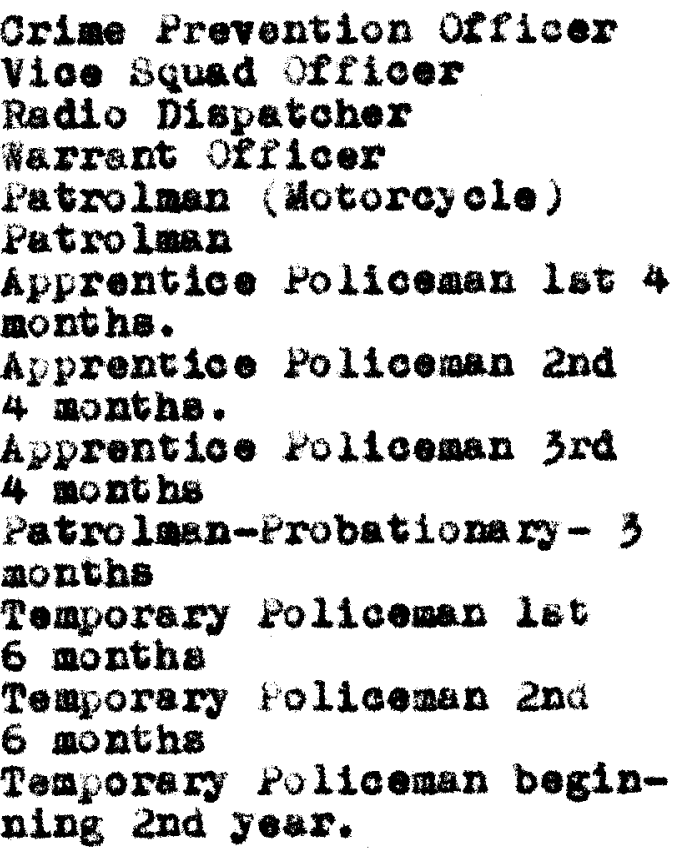 & 8 \\
\hline
\end{tabular}

SAM ANTONIO

Base pay for patrolman \$2040.00

MASHIVORON

SKATILTE

onter

Asolstant Chier

Deputy oni of

Inupeotor of Traffio

Captain 18t. Grade

captain and Grado

Chiel Jallor

sergeant lat Grado

Sergent 2nd. Grade

Protrolman, esignod as

Speciel tavadigator

Patrolnar, assigned as

Detective

Patrolinan 18t. Grade

fatrolman 2nd. Crade

Patrolman 3rd. Grado

Patrolan 4th Grade

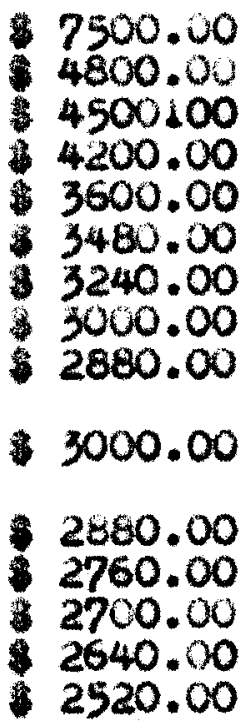


Sinatlas (continued)

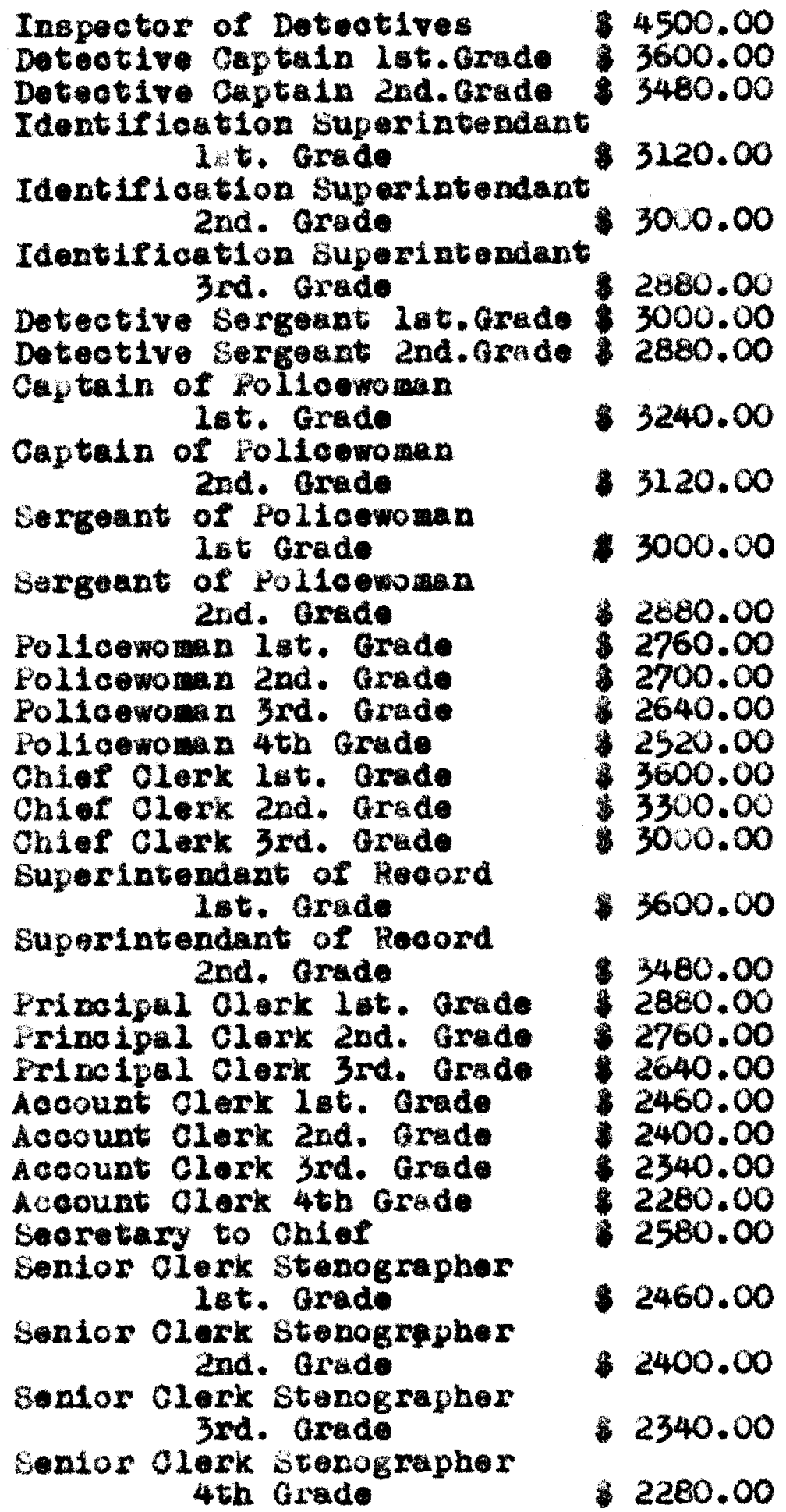


sparrus (continued)

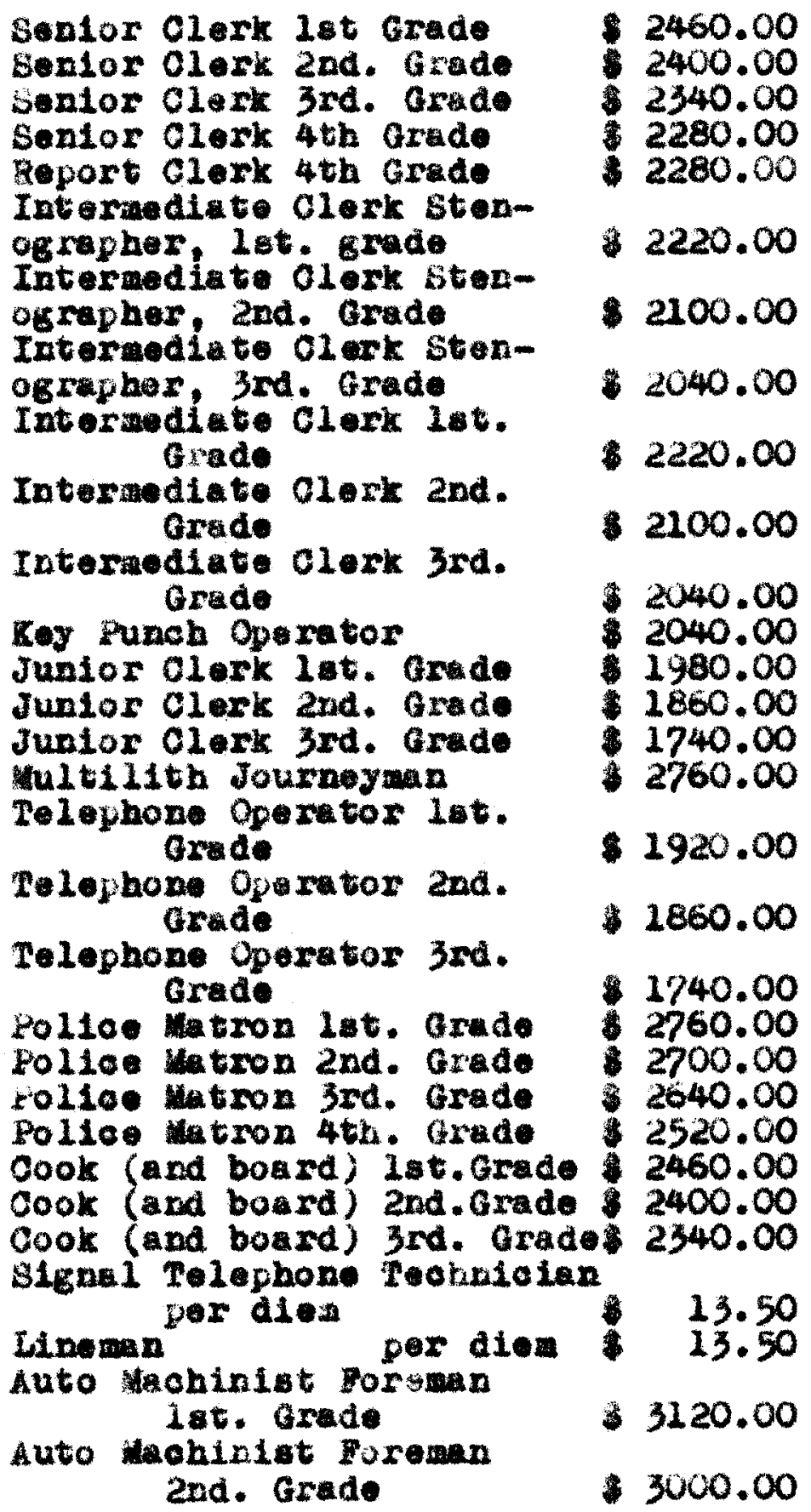


3andis (continued)

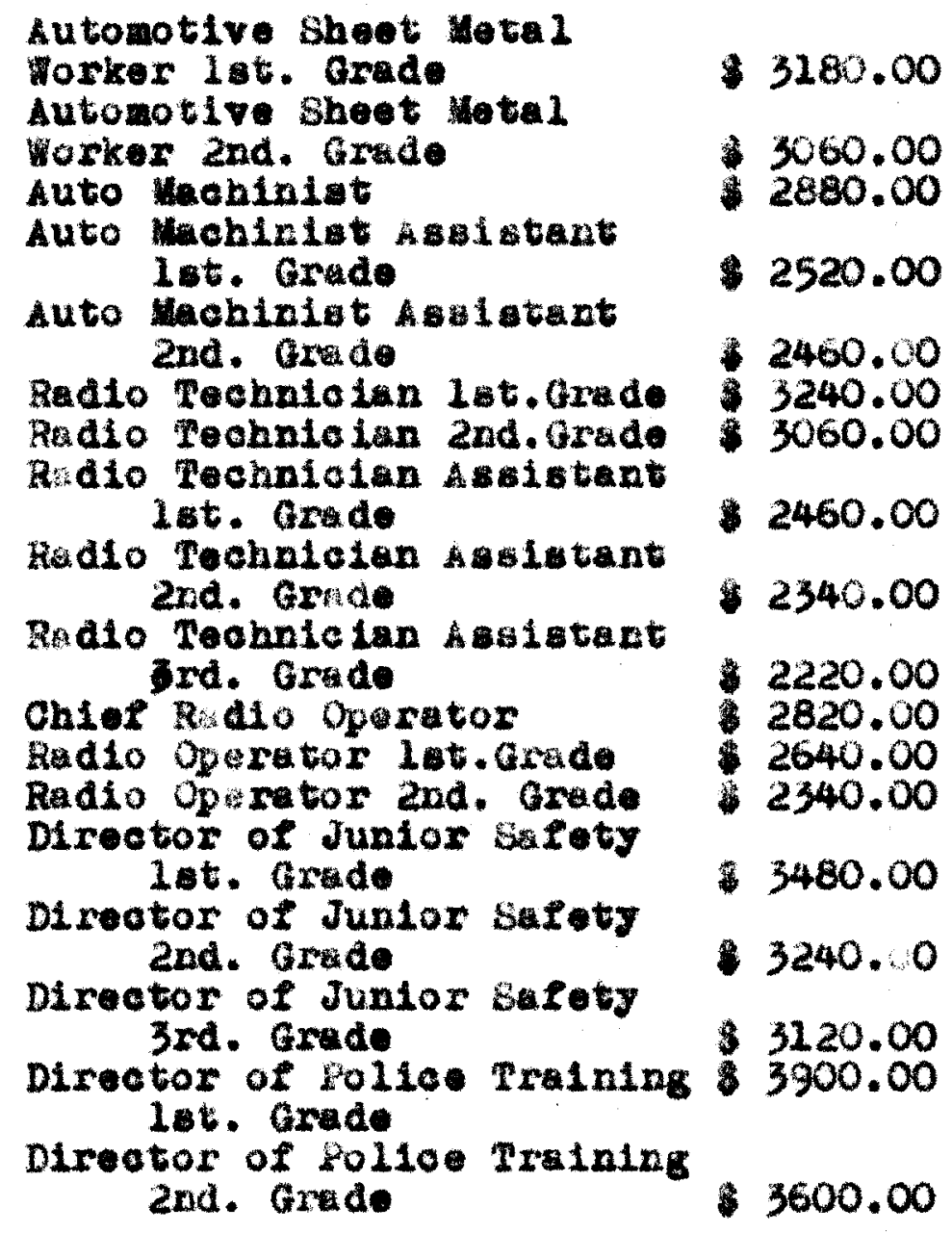

TSO JKS II

IItWAUKR

No Polloe Departwent anbwers received. 
Table 6

HOW WANY WON ARS ASEIGNDD TO THE PATROL SBOTION? DERECTYS SBCTIU?

ALABMA

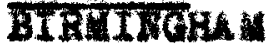

Patrol Seetion - 187. Deteotive Section - 36

QALTORNI

OANTAD

Petrol Section - 226. Deteot1ve seotion - 40

CuturaDo

DWurke

Wo answer to this question.

KANOOLY

LOUISVITLE

Patrol Section - 393. Detective Eection - 45

DOOTS TANA

FET ORtadis Patrol Section - 400. Detective Section - 100

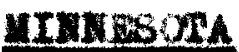

S2. RAUL

Patrol Section - 167. Deteotive Section -63

MEV Y YRX

KWCHEST

Patrol Section - 82. Detective Section - 36

QH10

CINCINKATI This question not answered.

Cocuxbus

Thls question not answered.

ToLabo

Patrol Section - 163. Detective Section - 51

Taxas

DAuths

Putrol section - 173. Detective Section - 80

SAS ANTONIO Patrol Section - 106. Detective Section - 47

MSHTEORON

BEATILE

Patrol Section - 325. Detective Seotion -92

AISOUNSIS

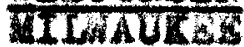

Do Police Dejartment answers reoeived. 


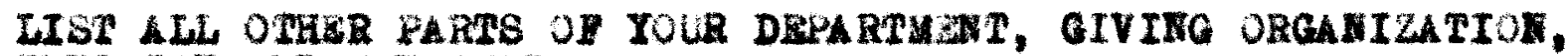

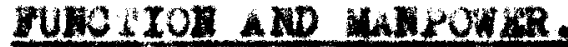

ALERLA

BIFIICHA

QkITORHTA OARTARD

KONUQSY

LOUTSYILLS
Traffic Division, haded by a captain of Polloe, composed of one tenosmpher. 21 totor Gycle offleers. 3 weoe Invostigators. 28 praffic offictre. Record Division hoded by a Record Cler, con1sta of 4 tenographers. Bureau of Identification under eupervision of the Record clerk, maned by 3 Patroluen and a Juntor Clerk.

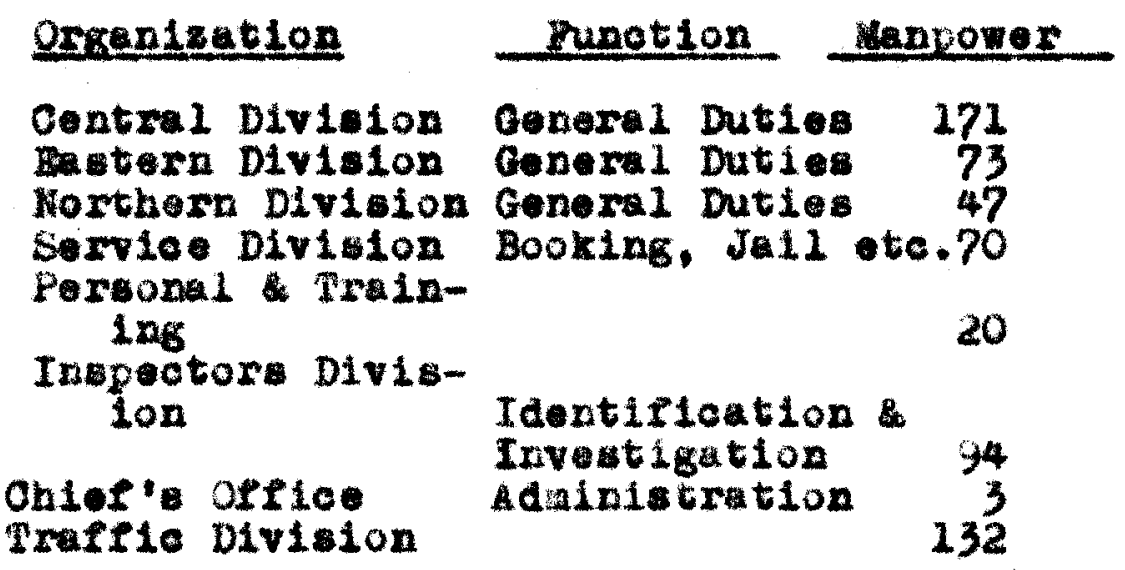

Trafflo Bureau conprised of 90 members lnoludes the Vloletion Section, Aceldent prevention section, Enforoment section. Taxi Gab Inepeation Section and the Briage Aalgnnent. The Crine prevention Bureau comprised of 10 mombere 18 comanded by captein. The sacation section Ls comprlsed of 4 wobort and headed by a captain. Iho Reoords una raentif1cotion Bureau is commendod by the chlef of Detectives and 1neludes 8 menbers - 11 as 4 olorke. 
LouTg LAN

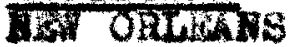

ITASOOLA BH. PAVL

DLN YOR ROORKSTER

OLIP

CInorran

Columbus

TOLIEO
Identifiostion Bureau of Reoords. Radio Comanuleations and Telephone operatora. Fawn shop suparvisor. Hisaing Peraone and Jevenile Delinquency Buroau. suto Theft Bureau and Bicyclo Divioion. Auto B votorelo Repair Shop. Trafilo Division. Palnt bhope.
Follce owitchbourd operators Radio Divigion Polloe Dootors

Identifioation Division

Pol10e Momen

Polioe Natrons

Trafele division

Malntenanoe Repairs

superintendant of school Pol10e

Heenes Diviaion

Property Clexk

Target Range

Reco rds

Stations

Taxicsb Inspeotion

Milaing $t$ rwon:

hocident Investigation

7
7
5
6
4
4
26
1
1
5
2
1
22
2
1
1
1

Acoident Bureau

Traffio Bureau

42

52

Th1 question not enswered.

Traficio section

Headquartere Section

Record Seotion

Communioution Soction

Jatl section

Comanication

Traftio Bureau

Bureau of Identification Record

Crite Frovention

fomen' Bureau

15

35

13

8

4 
Aass

Dantas

Tratile bureau, pollee tralning.

Reoord' Buresu, varrant Off1oers, Auto fourd Detail.

SAX ALROLIO

Beoord Division

Vioe Divielon

18

Matntenanoe Division

Veblole UeIntenane

tocounting

14

16

12

5

LSIINOTOH SkAlThis

Praftio Diviaton, Technioal s.rvices Divis1on.

HSOONSIX

MUATUE

No pol10e Departinent answere reedved. 
Tab1e 8

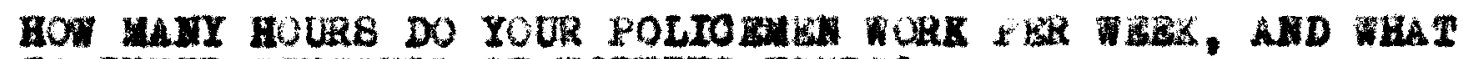

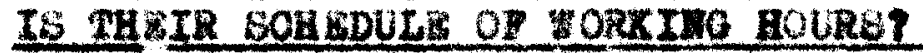

\section{ArdBay}

DTRTMLAL

CALTOWIL

OARLABD

OOTOLADO

Dirhverit

TIXOCX

Boursinters

LOUTBTANA

ABT ORTERHS

MXITSOA

3T. RAUL

WLE YORK

ROOHESTHR

ORTO

OThondet

Columbus

TOTEDO

$\operatorname{cothS}$

DANLAS

BAN ANTOITO
48 bours per woek. 8 hours day

1 day off owoh woek.

48 hours for weok. 8 houre por day. Overuine pald for houre worked in axcess of 44 hours a weok.

48 hours per week, 8 bours gar day. 4 naye oft per nonth. 15 day vacation wth pay pex year.

56 bours per week, 8 hours day. Wexy Bth day off.

40 hours per woek. 8 hours a day. Oef 1 day weok.

48 houre per week. 8 houre day. 1 day ote par veak.

48 hours per week. 8 hours a day. 1 day oft par woek.

Ple questos not answered

48 hours per woek, 8 hours day. 1 day off per woek.

48 hours per week. 8 hours a day. 1 day off per weok. 12 daye vasation por yoax.

48 hours per week. 8 hours day 1 day off pex week.

48 bouxs por week. 8 hours a day 1 day off per week. 
121

WoAILGROR

Bantids Follcemen work 44/2 hours per wook

1 day off very 5 daye.

VISOOK8II

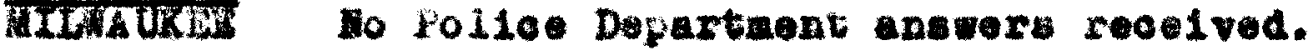


ARE OHIPORUS AND ARMS PURISHED BRER? IF NOT, WHAT ARE

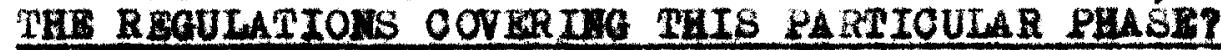

ALAMUA

BIRE IntotaA

CALTRORWIA

OALIAKD

COLORADO

DENVER

KanPuCKY

LOULSVIILE

IOUISTAKA

DEV ORLEANS

MINMBSOMA

ST. PRUL

1.2A YORT

ROOACESTW
Ho. Each man furnished his own equipment.

No. Deb man furnishes his own equipment.

Uniform cloth is furnishedtto all men, but thoy aust pay for tayloring. Sar Brown belts, holsters, nlght atloks, patrol box keys, cap shleld and rule book are furniohod by the city. Guns and anmunition are furnished by the offlcers.

Untforas are furniahed by the nen. Pire arms, san brown belts, holsters, and flashight batteries are furnishod free to all of ficers.

No. Bach man furnishes his ow equipment.

No. Enoh wan furnishea his own equipnent.

Finter Reefers are furnished by the city to all chauffours and motorcycle officers. Caps are furnished to traffic offloers and accident bureau officers. Revolvers, hend cuffs, and bedges are al to furnished by the oity. Puttees, worn by corner men oniy, are also furnished. Rainooats and boots are furnished notorcycle offloers. 
OIIO

CIHO INKA

OOLWMBUS

TOLIEDO

TCXas

WALAS

BM ARTOIIO

AAKTLONOS Batrut

TONOTSTH

TILTWEN
Phis question not answered.

Axme are furvished free. Men purahese thelr own unterne.

ach uniformed officen is dien 25.00 yeaxly, toward purohate of required unifora stielas. hra are Iurnishod.

\$ 75.00 are given ouch your to each man for olothing and other necessitied.

bay arms turalshed.

Plre arm and other specis 1 equipnent are eurnished. Len nust buy the Ir own unleorms.

No Po 110* Depantmont anewere necelved. 


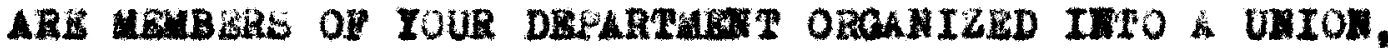
IXDKPBAD CONEIBED TO BAROAININO RIOKTS WIT THE OTRY, OA DOES IT INCLODE THE RIGHT TO STMIRE?

ALABA Bus

BIR⿴囗十 Ho.

CALITOREIA

OAKThD

No.

OOLORADO

DESTER

Affils.ted with the A. P. of L. Mlght confined to bargulning wth the city. No right to strike.

Rentuox

WOUSVILE

A portion of the personal is afPlilated with the $A$. F. of $L$. but I. not reoognized by tho oity. The depertment has pollce Assoclation comprising over $95 \%$ of the entire personal. This is the the rooogniged bargalning agent. The organization also pajs sick and douth bonefits.

DOU TO LANA

IEN ORLEA Ws

No.

Mrungersera

ST. PAUL

No.

IED YORX

RoCHESTH

No.

ogro

OTHC INTARI

Thle question not andwered.

CoLUMBUs

A fraternal onder of pollee. No right to strike

TOLIODO

No. 


\section{5}

POAS

WKLLA

No.

SAK AEROLTO

No.

DSOHIMGROE

bertothe

No.

IScousT:

Iruanuare

No Polloe Departaent answera reoelved. 


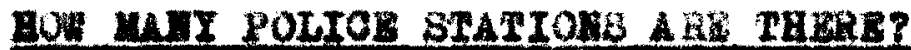

AIDBAY

BItruthora

CLIPOHLA

OARTWDD

OOTORANO

binVER

SITPUOKI

ToULSVLIST

TOUISTA MA

The okturas

IIUNBSOMA

BI. PAUL

HET YORK

20012TSLPR

otro

ox ormat

corvutaus

TOLDDO

TRLS

ixnos

Bax Aaromio

IASHIECDOL

BrathI

ISOOSST:

EUALULAE
2

3

This question not enswerea.

The elty at present, has 1 central Hoadquarter. Thls setup has been in effect for 5 years, but his provea inefficlent. Before this plen was inaugurated thexe existod 4 beparato atations and Hoadquarter's atation. Plans are under way to return to thia orgunlation.

1

7

7

9

2

1. Two substations are contonplabed.

$\mathbf{1}$

3

No Polloe Departinet ansmexo reestred. 
Table 12

SHAT IS PREIR LOCATION PLAM?

ALABESA

Brmantar

QALIPORNTA

OAKLAND

COLORADO

DETYha

ERT2uCXY

IOUTSVILTe

IOUIB IANA

IEW ORLRANS

MTINBSOP

BT. PAUL

BEI TOR

TOOLEBTHa

OnIO

ONTOLARET

COLUMBUS

TOLEDO

Pars

DTHAS

DAN ANTOEIO
The Central station sesves as a headquarter. while the Ensloy substation take care of the western Seotlon of the c1ty.

Stations aro centrolly 10 oatod within tholr diatrictio.

Mo anewar to this queation,

Whis questiontanswered in question 12

2 atation ary lonated in the commercial divilot, 5 in the resldentlal areas.

Headquarters is loceted in the center of the elty.

Buch station 10 located in the conter of 166 diterict.

3 atutlons axe localed in the commorolal distriot, 4 in the residential areas.

Eetiquextere is lockted in the down town axea. The other stations are soabtered throushout the e1ty.

The river divides the two districte.

Headquartarn 18 loosted in the down town bection.

No answex to this question. 


\section{8}

SASTROPOL

BEATLLE

TSOONEIS

TILAUKS
Located in auch a mannex as to be not nearly asaessible to 2.11 parts of the arses they serve.

No Folloe Department answers reostred. 
WHAT TYYES AND HOW MEY PLDES OR WOROR YGHIOLES DO YUU HAVE?

ALAMA

BTarinchar

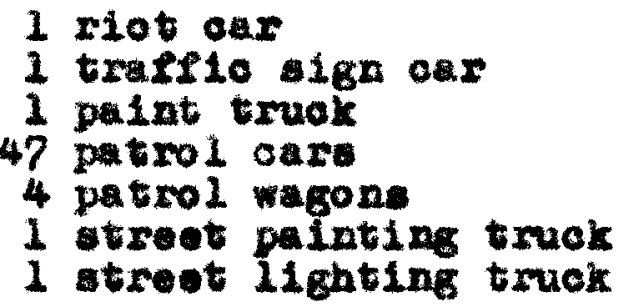

GarTonIu

OAKLAD

5 ambulanses

4 patrol wagons

101 patrol oare

72 motoroyoles

COLOLADO

Davina

2 ambulanes

2 patrol wagons

1 paint truak

- exvisere

92 patrol cara

19 motoreycles

KATUOEX

WOVISTILt:

66 two-may radio patrol ars

2 heavy-duty 17 paseenger ambulanocpatrol-combinations

6 ten pasenctax-anbulano e-anergenoywagons tro-way P.4. radio for all wagons.

30 motorcyoles

3 three meelere

2 energeney wreckers

1 energenes 11ght truek

LOUTSIIIS

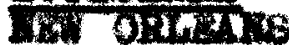

66 patrol cars

17 trucks and ptrol wagons

62 motomoy cles

MINEHSODA

Bi. PAVI

39 patrol care

5 trueke

1 patrol wagon

2 ambulanee

1 plokup truck

12 notoroy cles

2 three wheolers 
Ex 192

xookBsw

38 patrol care

1 patrol vagon

1 radio tmuak

21 motoreycles

OHIO

TIKTHNATI

225 patrol caxe

30 notoreyeles

8 patrol wagons

2 truoks

COLUUBUS

45 patrol cars

30 motorayolea

6 throe whelex

2 patrol magons

2 ambulanoe

TOLEDO

10 patrol anbulanoe

65 patrol cars

30 motoroyoles

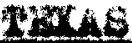

DALLAS

121 catrol caxs

34 three wheelors

31 motoreyeles

3 wreckers

SAL AMROXIO

80 patrol care

16 totoroyeles

WASTHCROL

SWATH

a3 patrol cars

38 motorayoles

8 trucks and wagons

M TBOOHSI:

TILAR UR IF

Lo Follee Departient anemers reodved. 
Tabl• 14

GIVE FHE AVM2AOE $\triangle$ OF OP YOUR YMRIOLES

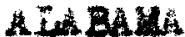

BItRTKGHA

3 yoaro

QALISORHIA

OKRLABD

9 yoare

OOTORADO

Deringar

Tala question not answered.

serruox

60018010T

6 wonthe

LOUTSIAN

Fit ORLines

1 ke yeare.

1ITH 2002

ST. FTUL

$3 y \operatorname{sen}$

ADI $\mathrm{TON}$

TOCRISTIR

1 reax.

OHIO

OINRTXAT

Thi question not answexed

COLUHAU:

5 yeare.

TOLEDO

6 yoars.

$2 \mathrm{EAO}$

DALTSS

1 year.

Bâ A N2OLIO

3 years.

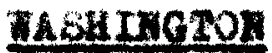

SHATH:

4.5 yeare.

TEOONSTE

atcaturs

No Polloe Depets nt answers reselved. 


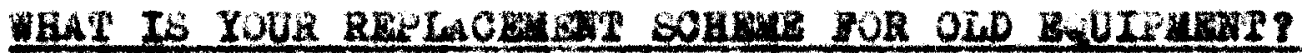

AIMBAYA

Btantagan

QALTORIA

OALALD

COEORADO

DEATHR

Garooxy

DOUIBVILIS

LOUTS IANA

WEA ORLEAS

ULESSOLA

ST. PAUL

IST YOR

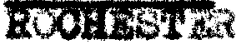

OHTO

ETRUIRW II

cotoutbus

ToLt00

20\%AS

DKTwers
Vehicle ariven 70 to 80000 alles are replaced by new equipment.

Replace oldest equipaent when now vehioles can be purchased.

No answer to this question.

Vehle les driven 50000 illes are replaced by new equipment.

New equipent purchase when budget M110:8.

Vehicles driven 200000 allea are roplaced by new equipment.

Vehicles driven 60000 alies are replaced, if possible by new equipment.

No ander to this question.

Replaoenents ade whon budget allowe.

Contemplated replacement this year(1947)

20 perol okrs, 6 ambuls ne patrols,

29 notorcyoles. Pretent equipment in

it poor condition.

The motor vehloles of the Dallas polloe Departiant are rented on a ponthly milage basis of 5 t per alle. The purchese and service of all motor vehiele -quipment owned and opersted by the city of Dallas, inoluding the pollce Departient, 18 furnished by the thinloipal carage, and purchases are belng nde noeded through locel dealors. 
Fras (oontinued)

SAI AmonIo

MASHICCOS

B.MTTLE

ISOONSIX

VILWA UKEE
Veniclea re traded in.

The depertaent repiaces 411 vehicles on depreciation besis.

Ho pollce Departmont answera reoulved. 
Table 16

GIVZ SPATISTICS OOVBRIWG CRIME IN YOUR CITY, DURIHO THE PAST 5 YBARS.

ATABALA

BInITCLa

QATEORNIA

OAKTAND

COTOKADO DLIVISR

Manucre

DONLSVI,

CoUTS IA VIA

BET JWLRH

INWWSOMA

ST. PAVL

Maiv YORK

Tockeston

OrIo

CIACINKATI

OOLULDUS

TOLEDO
Wo ander to this question

$\frac{1941}{31602} \frac{1942}{126927}-\frac{1943}{109806} \frac{1944}{128747} \frac{1945}{121425}$

Pleves represent number of offenses for each yoax.

$\frac{1941}{7137} \frac{1942}{7520}-\frac{1943}{7494}-\frac{1944}{6966}-\frac{1945}{7732}$

Pigures represent number of serlous offenses only.

$\frac{1941}{9967} \frac{1942}{8995} \frac{1943}{7652}-\frac{1944}{8391}-\frac{1945}{9488}$

Plgures repregent number of serious offenses only.

Total or anjox offonses 1941 through $1945:$ 23443

$\frac{1940}{4061} \quad \frac{1941}{3508}-\frac{1942}{2992} \frac{1943}{3093} \frac{1944}{3180}$

Wo answer to this question

$\frac{1442}{8660} \quad \frac{1443}{7556} \quad \frac{1944}{7441} \quad \frac{1945}{8126}$

Plgures represent number of cerious offenses only.

Vo answer to this question.

$\frac{2941}{5232} \frac{-1942}{5633} \quad \frac{1943}{5215} \frac{1444}{5300}-\frac{1945}{6580}$ Plgurea represent number of corloue offenees only. 


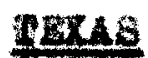

Dothess

$\frac{1941}{10956} \quad \frac{1942}{10763} \quad \frac{1943}{7971} \quad \frac{1944}{9591} \quad \frac{1945}{10014}$

P1qures represent maber of serious offenses onily.

SAN WNOTO $\frac{1941}{4769}-\frac{1942}{4795} \frac{1943}{4544}-\frac{1944}{4308}-\frac{1945}{5043}$

Pigures represent number of serious offenses only.

WSHTCOTOH

BLATTW

ISCOTSTE

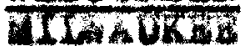

This quection not answered.

Do Polleo Dopartment asswers rockived. 
DESORTBE THE POLTCE RACTO AND CALL SXSTM.

ALA DAWA

DIRTINGHA

OALTHUITA

DRRLKD

COLORADO

DUNVER

SGWTUCKX

LOUTBVTLL

LOUTS IARA

DLW ORLEANS

MINKCDORA BT. FLUL

N TORK ROCRLSTER
Tro-wey woter for all patrol care.

7. H. radio syeton for all vehicles. as weil as Ganevell call box gysten.

Oomplete radio and tolophone communication systom.

The alty wes one of the ficst in the woxld to have pollce rallo oommunloation aystem. It $1 \mathrm{~s}$ the laxgert aimsle-transmitter unit gtation in tho world, oporating on an DU Irequency. It serves not only tho Folloe vahiales, but also the Dopertsent of works, the Fire Dapartment and - antion of the Kentuoky State Highway patro 1. It has sorved as an examplo to wany other cities and has been coplod by many hustrallan folloo Dapartaonte. Loulsville wa also plonese in the Insialiation of a rado telograph syater. The polle Departant teobricians have developed ecret antenne for pollos care which cannot bo seen. The Polle Department also oporates a complote Gamerall call box aysten.

polloe radio sycton.

Pollo radio byttom coordinated network ath two surrounding counties and two sunicipalitios.

Polioe radio syeten. Ooordinated notwork wintained with neighbouring rolico comanioations aystar. 
OHIO

DikO INRHAI

COLOMBUS

TOLBDO

waxis

DATIRS

SAN ANRONIO

WASHINONOT WEATHE

TISOOHSI盾

MIDA. OW
No answer to this question.

Three-wey M. Hollce Radio syetem.

Pollce radio aystar.

polloe rado syatem.

polloe rudio systea, Gamewall call box syaten for down town area.

pollo radio syevem for A.K. Also

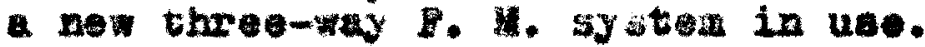

No frollce Desurtant answers received. 
The anwers to the survey questionnalres sent to the o1ty of Indianapolis ware reculvod too late to be inaluded within the eurvay index and satistical tables, nor could they be thoroughly interwover within the andjtionl sections.

However, the flre department and police depertment anewors are 11ated in complete form in the following suppleneatary tables. Ho safety depertment anawers were received from Indianapoiia.

Whore Indianspolla is not included within the body of the anulyela, it will be found mentioned in the footnotes of the amalytical sections. only in the above-mentlonea proceedure was it posible to give complate cov rage to these late ruturns. 


\section{PART III}

GPEOLAL SLAFLETENAARY TABLE

DTAS DLFAKTW

INDIAKAYOLIS 
1. HON MAY DISRRTOSS ARE TKGHO 4.

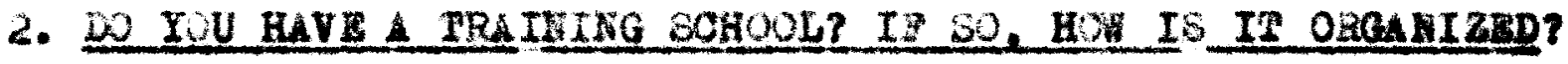
Yos. Batallion chief in charge, with authorized asistants.

3. WIAT ARE THE SUALTU TOAPIONS RUR JOINING YOUR DE ARPUENRT Age: 21 to 30. All applloants aust pase phyaleal examination.

4. HOF BAHY BUIFOY 608

5. WHA IS THE SAZARY SOALE? 2400.00 to 6000.00

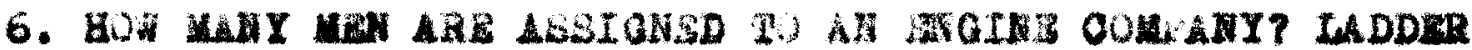
OUHANY?

Sulne Company: 5
Ladder Company: 5

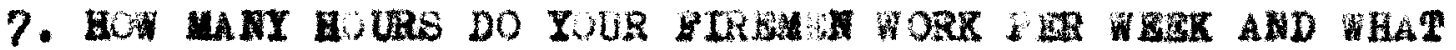
IS HARIR SOHBDULE OR WORKING HUURS?

84 hours. $24: 24$.

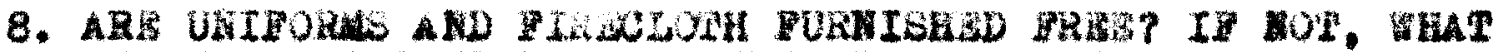

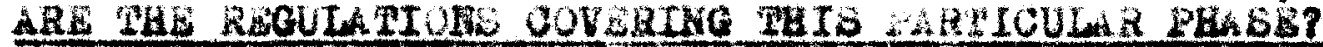
Clothing allowance of $\$ 100.00$ per yaar.

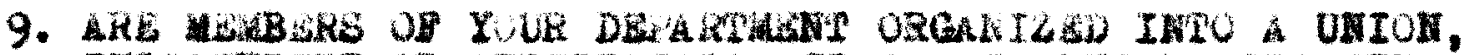
INDEP BNDENT OR AREILIATED? ID SO, IS UKTOE AOTIVITY CONINED TO BARGA INING RIGHES THH THS CITX, OR DOBS IT HAVE THE BIOH: TO OSRIKE? ATPiliated with the Intaruational Babociation of Are Plghtere, A.P. of L. Aleo the Indiana Firemen's Assoclation. The lattor is not affiliated with any union.

10. HOB WAMY IIRU STATIONG ARE THERE? 29

11. GHAT IS 2HOSR WOCATIOR LLAN?

Houses are located to seet local requirenerts. 
131

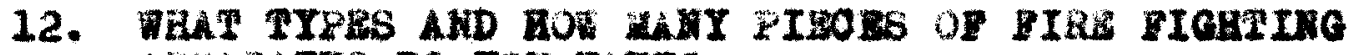
AYLARATUS DO YOU HAVE?

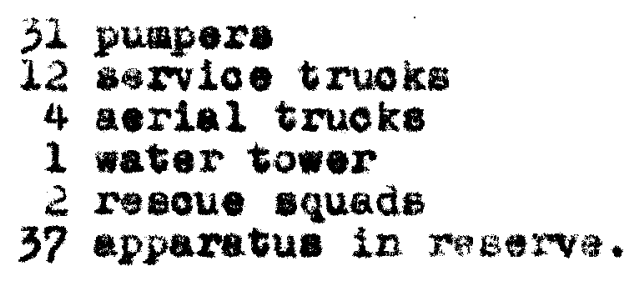

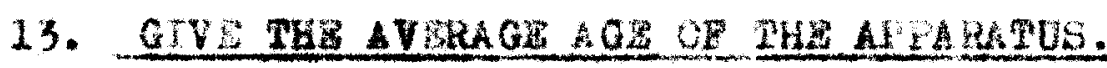
25 years.

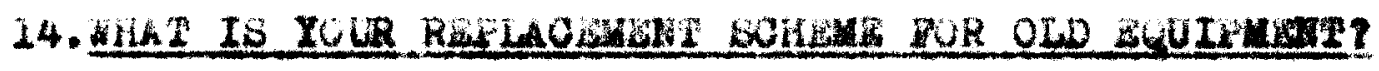

Feplacements are ande when the city can float a bond isbue. 9 now apgeratus were received during tho last ten years and these were built in the firo departm nt shope.

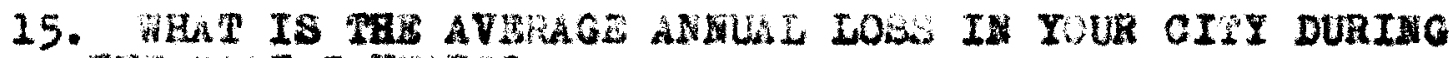
ThE HASP 5 Y MARE?

$$
\text { 647.916.97 dor cajta: } 2.1197
$$

16. DESCRIBE YOUR OLRE ALARM SYSTEM

Gancwe1.1 arsten. 
PARI III

BN BOLL BUPLIMARHAX PABLE

POTIOE DERARTH

IBDIAVAR OLIO 
1. HOW WAY DIOTRIOTS ARE THARE?

47 walking distriots, 16 radio ou districts, 4 diviaion sergeants distriots.

2. DO YOU HaVE h TRA INING SOHOOL? IP SO, HON Io IT ORGAIIZED?

Yes. The training sehool is organized under the gualifications as set out in the Aots of the Indian General Assenbly of 1935 and Amendments auplewent thereto.

3. WHAT ARE THE OUALIFICATIOKE POR JOINIFG YOUR DEPARTHTWT?

Age: 24 to 35. Height: uinimum S'7" Fe1ght: ainImus 150 1bs. Weight acording to helght. Wust pass rigla physical examination.

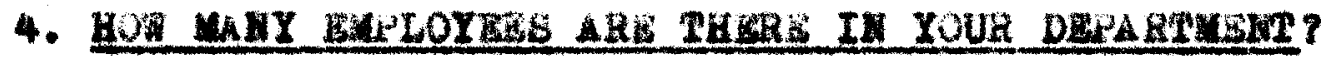
693

5. What IS THE SALRY BCALie?

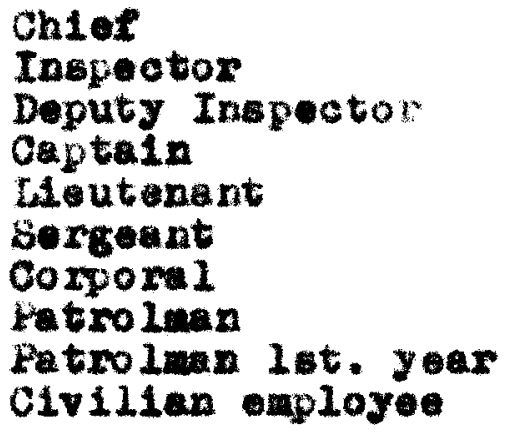

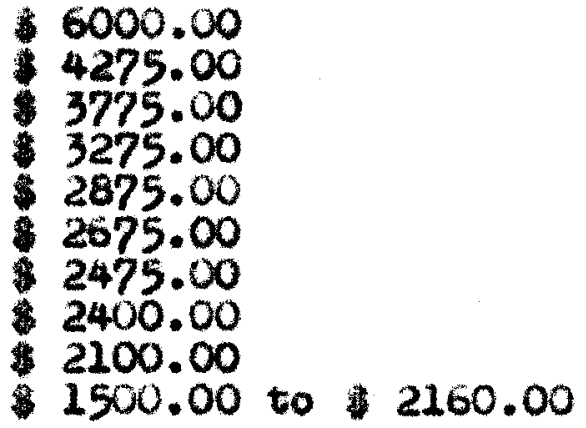

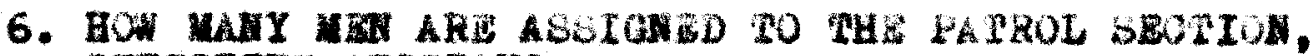
DETEOTVE SEOTIUE?

Detective mection 84

Patrol section 290

7. LIST ALL ORHER PARTS OR TOUR DEPARTM NF, OIVIMG ORGAXIZARION, FUYOTTOE AND MBPONER.

Chief's office - Chief of polles

Irspector's office - Inspector and secretary of pollce

Record Division - Sergeant and Corporal of pollce in cherge of 11 civillang who kdep department record plus 7 patrolmen wo axe telotype operators and 3 patrolaen who are regletration clerks. 
Property and Supply Division - 1 bergeant and 1 patrolnan plus 5 civilians.

Court Bullift - 2 bergeante and 4 jatrolmon

Gunan Department und subleipal Renvels - 3 sergente plue civiliano.

Gamewell Diviaion - 1 Sergesnt and 2 patrolmen Trafflo Maintenanos - 2 Sergednte and 12 Civillane Bullding Maintenano - 1 Heutenant and 9 civilians Muncipal Garage - 1 sergeant Radio and Communicstion Division - 1 superintendant of Radio and Comannlostion, 1 Aseistant superintendunt. 4 DoskLieutenants, 3 Dispato hing Sergeants, 9 Rad10 Operators, 8 Telephone operators, 2 Civilians.

Identification Division - 1 duptain 3 Sergeants, 3 Corporale, 11 patrolmen. 5 Pollce woren, 5 olvil-

Traftio Division Lans.

Acoldent Prevention - 1 Inspector of Traficic, 1 captain. Motoroycle Division - 2 tufeutenants, 9 sergeants, 3 Corporals 88 patrolmen, 5 Givilians. Juvenile Ad Division - 1 Lleutenant, 3 Bergeants, 4 Corporals. 9 Patrolinen, 19 Polloe women, I Oivilian.

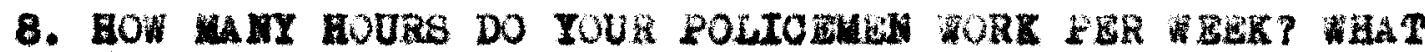
IS 24 IR SCHEDULE OP NOREING HOURS?

3 otght hour ch1fte. 7 days weak. Off the lghth day.

9. ARS UNIPORMS AND ARUS FURNISHED RHEE? IF MOT, WHAT ARE THE RGGULA ITONS COVGRTIG THIS PARTICULAR PHASE?

No. They aust be purched by the individual officer and muet conform to speoffications as oet out by the depertment.

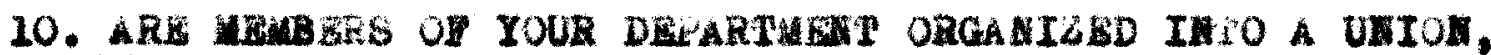
INDEPENDENT OR APRILIA 1ED? IP s0, IS UMION AONIVITY

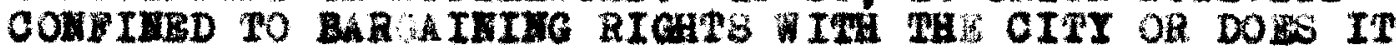
IXCLUDS THE RICHT TO STRIKE? Ho 


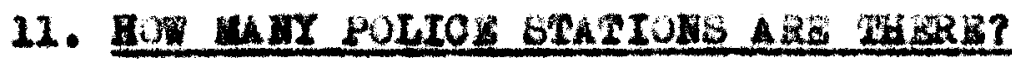

1

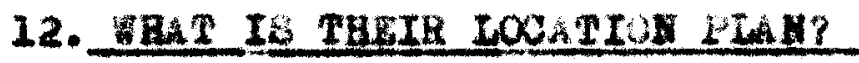
centrallzed plan.

13. MHAT TY Do You Haves?

80 vohlales. 42 motoreycles.

14. GIVE THE AV RAQG AOE OP YOUR YNHIOLE?

4 yoars.

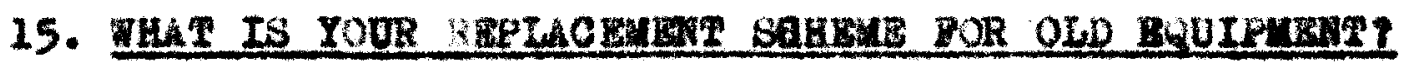
Sone equipwent is replaced asch year. Trying to anintain an average age of 2 jears for vehicles.

16. ATVE BTATISTTOS OOV ERIMG O IME IN TOUR OITX, DURIEG THE PAST 5 THARS.

Criminal Honoctie

Mansiaughter

Rape

Robbery

Assault

Burgl atry

Lareeny over $\$ 50$ axcept auto

Auto Theft

106

65

129

1612

1986

10211

2746

7061

only 5 yaar totuls given hare.

17. DESORIBE PHE POLIOE RADIO ALD CALE SYBTEK.

P. M. and A. M. two-way radio, Ganewell syatem. 
REPBREACE AND ADDITIOALL

BIBLIOGRA PHY 


\section{Bibllography}

\section{Goverment Documents}

Cov. Doo. O. W. N. Ho. 1, Ire Serleg, 1941, Adv18ory Comittee on ire Defense. Washington, D. 0 .

Gov. Doc. 0. C. D. Hundbook Bor Firemen, Training Section U. S. OFrice of Civillan Defense, 1941, A.C.T.D., Wabington, D. O.

Gov. Doo. 1.16. Pire Plghting, 1944, U. S. Government Printing utrice, whington, D. 0 .

Cov. Doc. 116 Aduss, O. D., Tralalne for The tolloe Service. U.S. Dept. Or the Interior, whington, D.C.

Gov. Doc. 993 - D Techniques of Lall Bnforcenent, 1945. Hodere 1 Socurity Agenoy, washIngton, D. 0 .

Gov. Doc 57 is Byer, H. B., Galarles apd Hours of Labor

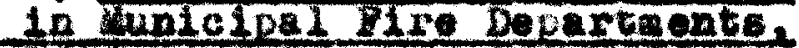
1940 V.S. Eureau of Labor Stetibtics, washington, D. 0 .

Books and Papphlets

Panphlet Ho. 96, Aotion Bor Citles, 1943, Fubilo Adninistion service, chioate. III.

Paxphlet No. 14, Information on Mupic lpal pollce mraininge. American Tuniolpal hssociation, W6shIngton, 0.0 .

Booke and Booklote

Bond, Horet10, Ire Defepse. Hret Bdition, 2941, Fationul Rire Proteotion Ascocietion, Boston, Hass.

Gaus, J. M. publio Adninistration, Frot Sition, 1940, Fublle Servioe Aasociation, wabington, D. C.

Henning, B. P., fublic sdainlatretion and the fubllo Interest. irat edition, 1936. Mograw, HIII Co., Hew York, I. $Y$. 
I.A.E.C. A Gulde For Freparing Annual Pollee Reporte 1935 . International Asbociation of Pollce Chiofs, Tashington, D. C.

Eentucky Revised statutes, 2nd. Rdition, 1944, Kentucky statute Revialon Commission, Prankfort, Ky.

Iny son, Capt. Burr, Plghting Plre, Sccond $8 d i t 10 n, 1943$, B. P. Dutton Co.. Hew York, $\mathbf{x}$. $\mathbf{y}$.

MoGannon, R. S., Fise Desurtaent Clvil Serviee Serles, Iret Eátion, 1946, kroo ivbilening co. Hew York, N. $\mathbf{Y}$.

Moulton, R. S. Matsonal Pire Codes.

Irat Baition, 1943; National Fire Protection Association, Boston, Mase.

Queen, S. A. 8 Thores, I. P., The 01 ty,

Iret Btition, 1939, MeGraw, H111 Colpany. 'Now York, $H . Y$.

Ridley, C. B.E Nolting, 0.8., The Municleal Year Book, published annually, the Internatlonal City Managers' ABsoelation, Chieago, Ilisnole

Sedlin, T., The Pollee And The Crine Problen, 1938, hemerloen houdeny of folitioal and Soclal solence, washington, $D$. $O$.

Snith, Bruce, Polloe gyetens In The Unjted states. Mrst Baltion, 1940, hafyer Brothera, New York, N.Y.

210x, Harold, Governant of C2tieg in the United States. Second Bdition, I\%4I, The Yosilian Co." Now Yoxk, H.Y.

Magazines

The Aparioan City, lasued wonthly, American C1ty fublishing Company., New Yoxk, M. Y.

Ife Fngineerlag. Issued monthly, Case-Shopperd Publ1cations, Hew York, $\mathbf{Y}$.

Hreaen, Issued Monthly, National gire Protection Aseoclation, Boston, Hass. 